Diagnostic evaluation of a multiplexed RT-PCR microsphere array assay for the detection of foot-and-mouth and look-alike disease viruses

B. J. Hindson, B. R.. Baker, L. F. Bentley Tammero, R. J. Lenhoff, P. Naraghi-Arani, E. A. Vitalis, T. R. Slezak, P. J. Hullinger, S. M. Reid, K. Ebert, N. P. Ferris, D. P. King

September 26, 2007 
This document was prepared as an account of work sponsored by an agency of the United States Government. Neither the United States Government nor the University of California nor any of their employees, makes any warranty, express or implied, or assumes any legal liability or responsibility for the accuracy, completeness, or usefulness of any information, apparatus, product, or process disclosed, or represents that its use would not infringe privately owned rights. Reference herein to any specific commercial product, process, or service by trade name, trademark, manufacturer, or otherwise, does not necessarily constitute or imply its endorsement, recommendation, or favoring by the United States Government or the University of California. The views and opinions of authors expressed herein do not necessarily state or reflect those of the United States Government or the University of California, and shall not be used for advertising or product endorsement purposes.

This work was performed under the auspices of the U.S. Department of Energy by University of California, Lawrence Livermore National Laboratory under Contract W-7405-Eng-48. 


\title{
Diagnostic evaluation of a multiplexed RT-PCR microsphere array assay for the detection of foot-and-mouth and look-alike disease viruses
}

\author{
August 30, 2007
}

\section{Primary Author:}

Benjamin Hindson

(hindson1@,llnl.gov, 925-423-8667)

\section{Co-Authors:}

Brian R. Baker, Lance F. Bentley Tammero, Raymond J. Lenhoff, Pejman Naraghi-Arani, Elizabeth A. Vitalis, Thomas R. Slezak, Pamela J. Hullinger

$$
\begin{gathered}
\text { Lawrence Livermore National Laboratory (LLNL) } \\
\text { Livermore, } C A
\end{gathered}
$$

Scott M. Reid, Katja Ebert, Nigel P. Ferris and Donald P. King

Institute for Animal Health, Pirbright Laboratory, Pirbright, Woking, Surrey, GU24 ONF, United Kingdom 


\section{Executive summary}

A high-throughput multiplexed assay (Multiplex Version 1.0) was developed for the differential laboratory diagnosis of foot-and-mouth disease virus (FMDV) from viruses which cause clinically similar diseases of livestock. This assay simultaneously screens for five RNA and two DNA viruses using multiplexed reverse transcription PCR (mRT-PCR) amplification coupled with a microsphere hybridization array and flow-cytometric detection. Two of the seventeen primer-probe sets included in this multiplex assay were adopted from previously characterized real-time RT-PCR (rRT-PCR) assays for FMDV. The diagnostic accuracy of the mRT-PCR was evaluated using 287 field samples, including 248 (true positive $n=213$, true negative $n=34$ ) from suspect cases of foot-and-mouth disease collected from 65 countries between 1965 and 2006 and 39 true negative samples collected from healthy animals. The mRT-PCR assay results were compared with two singleplex rRT-PCR assays, using virus isolation with antigen-ELISA as the reference method. The diagnostic sensitivity of the mRT-PCR assay for FMDV was $93.9 \%$ [95\% C.I. 89.8-96.4\%], compared to $98.1 \%$ [95\% C.I. $95.3-99.3 \%$ ] for the two singleplex rRTPCR assays used in combination. In addition, the assay could reliably differentiate between FMDV and other vesicular viruses such as swine vesicular disease virus and vesicular exanthema of swine virus. Interestingly, the mRT-PCR detected parapoxvirus $(\mathrm{n}=2)$ and bovine viral diarrhea virus $(\mathrm{n}=2)$ in clinical samples, demonstrating the screening potential of this mRT-PCR assay to identify viruses in FMDV-negative material not previously recognized using focused single-target rRT-PCR assays. 


\section{Table of Contents}

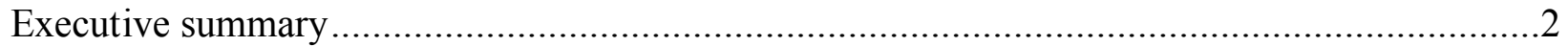

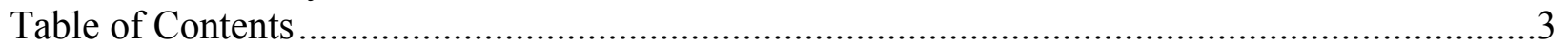

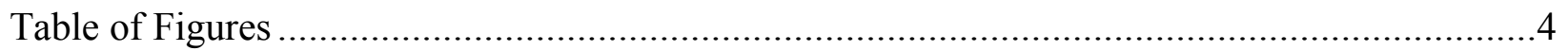

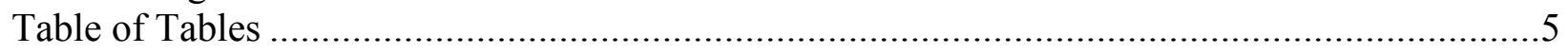

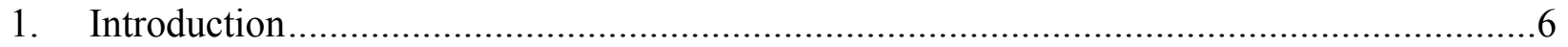

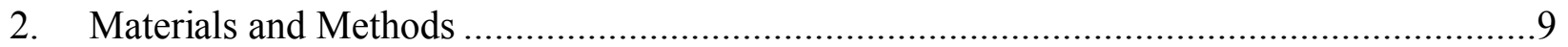

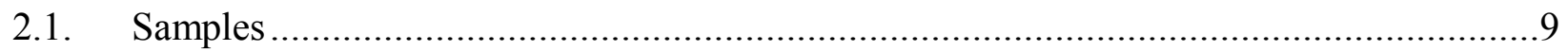

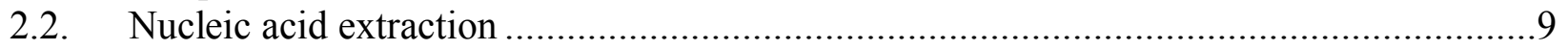

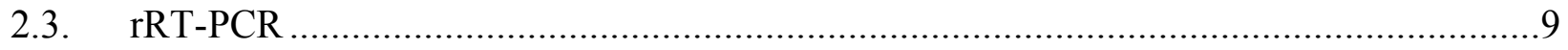

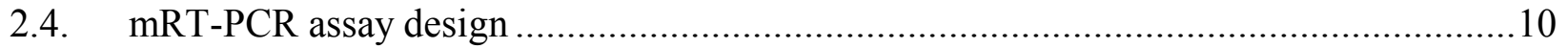

2.5. mRT-PCR primers and probes .................................................................... 13

2.6. Coupling of probe oligonucleotides to microspheres ................................................ 13

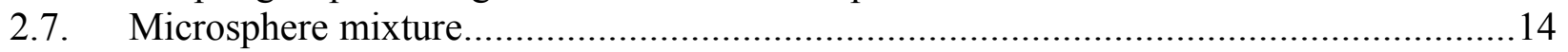

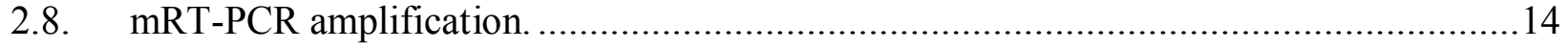

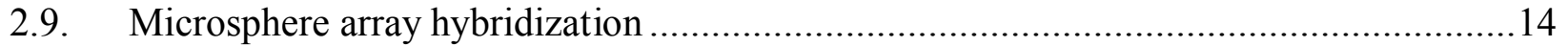

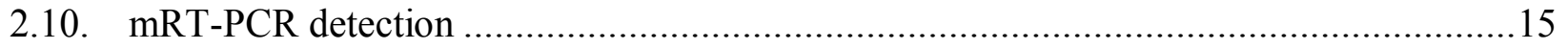

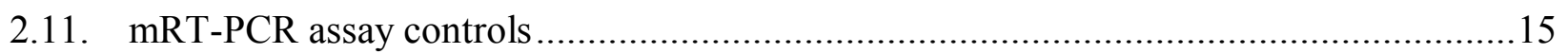

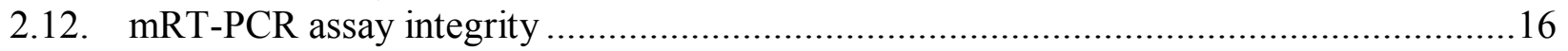

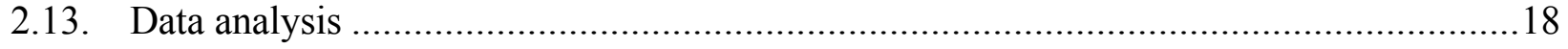

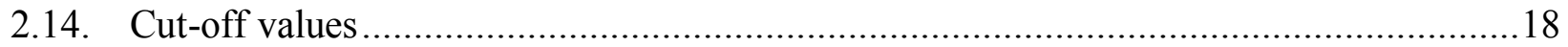

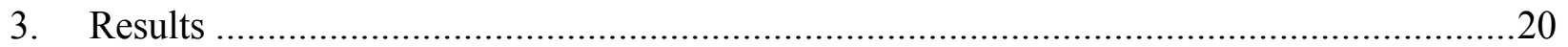

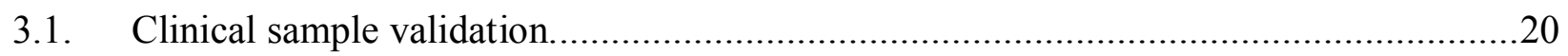

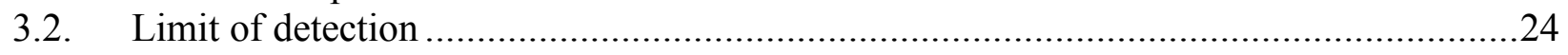

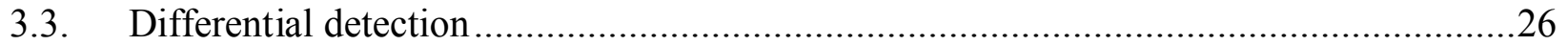

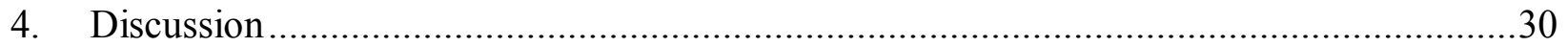

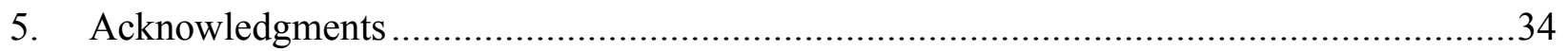

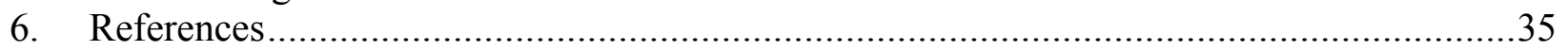

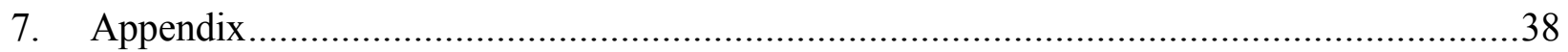

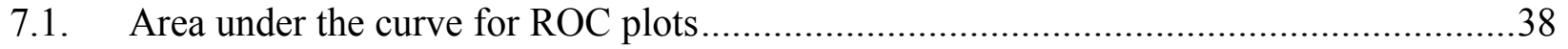

7.2. Receiver Operating Characteristic (ROC) Plots..........................................................39

7.3. Response of 3D mRT-PCR assay vs 3D rRT-PCR assay

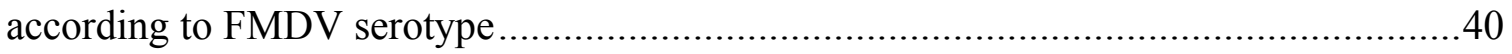

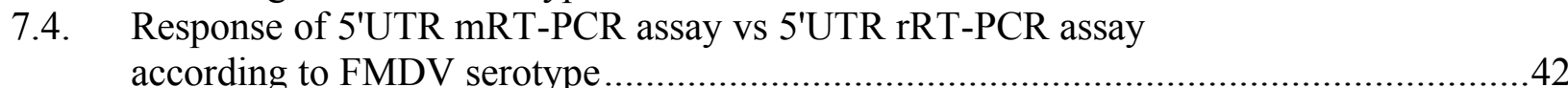

7.5. Calculation of performance estimates ............................................................44

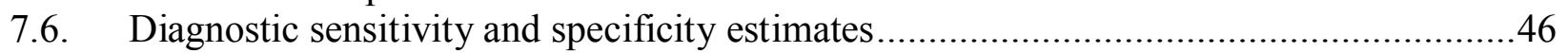

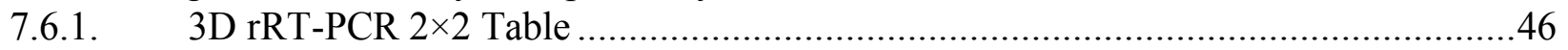

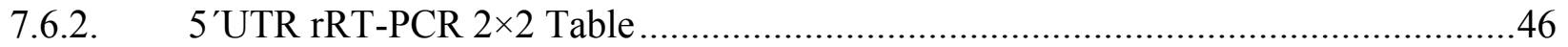

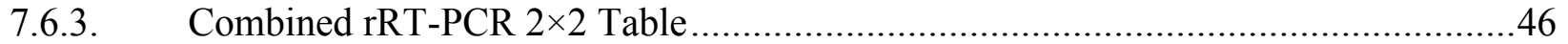

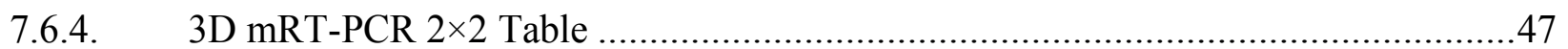

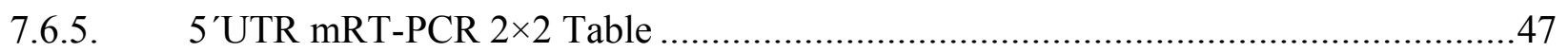

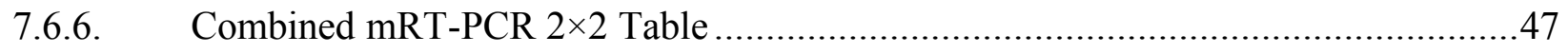

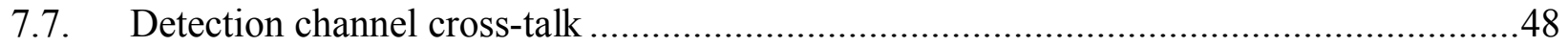

7.8. Raw data for 287 samples used for the diagnostic evaluation of the mRT-PCR assay.....49 


\section{Table of Figures}

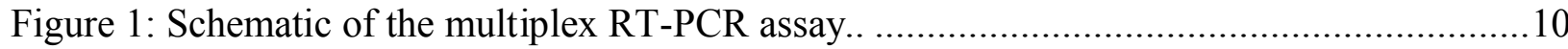

Figure 2: Algorithm used to verify mRT-PCR assay integrity .......................................... 17

Figure 3: Receiver Operating Characteristic (ROC) plots for the 3D and the 5'UTR assays in singleplex rRT-PCR and mRT-PCR formats ...........................................20

Figure 4: Comparison of the 3D and 5'UTR assay responses in mRT-PCR and singleplex rRT-PCR formats. .25

Figure 5: Multiplex RT-PCR assay identification of FMDV look-alike disease viruses in suspect FMDV clinical sample submissions.

Figure 6: ROC plots for independent 3D and 5'UTR assays in rRT-PCR and $\mathrm{mRT}$-PCR formats according to individual FMDV serotype and for all serotypes.

Figure 7: Comparison of the 3D assay response in mRT-PCR and singleplex rRT-PCR formats .

Figure 8: Comparison of the RNA polymerase (5'UTR) signature response in mRT-PCR and singleplex rRT-PCR formats. 


\section{Table of Tables}

Table 1: Primer and probe sequences of the multiplex RT-PCR assay. ..................................12

Table 2: Cut-offs for each detection channel of the multiplex RT-PCR assay.........................19

Table 3: Performance metrics for the 3D and 5'UTR FMDV assays in rRT PCR and mRT-PCR formats using independent or combined results. .....................................22

Table 4: 3-Way comparison table for the combined results of 3D and 5'UTR assays in

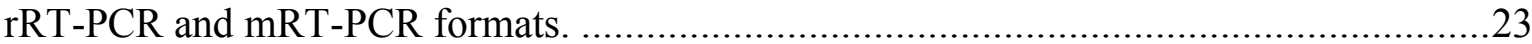

Table 5: Area under the curve for ROC plots for the independent results of the 5'UTR

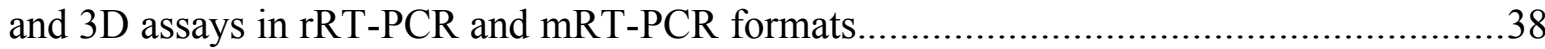

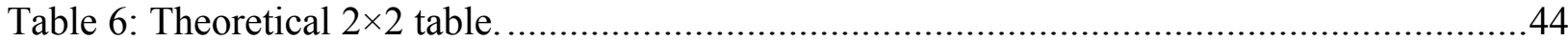

Table 7: 3D rRT-PCR $2 \times 2$ table using VI with Ag-ELISA as the reference method. ................46

Table 8: 5'UTR rRT-PCR $2 \times 2$ table using VI with Ag-ELISA as the reference method...........46

Table 9: Combined rRT-PCR $2 \times 2$ table using VI with Ag-ELISA as the reference method.......46

Table 10: 3D mRT-PCR $2 \times 2$ table using VI with Ag-ELISA as the reference method..............47

Table 11: 5'UTR mRT-PCR 2×2 table using VI with Ag-ELISA as the reference method........47

Table 12: Combined mRT-PCR $2 \times 2$ table using VI with Ag-ELISA as the reference method....47

Table 13: Correlation coefficients between the mRT-PCR FMDV 3D or 5'UTR detection channels with the other fifteen detection channels.

Table 14: Raw data for 287 samples used for the diagnostic evaluation of the mRT-PCR assay. 


\section{Introduction}

Foot-and-mouth disease (FMD) is a highly infectious and contagious vesicular disease affecting domestic and wild ruminants and swine caused by a single-stranded positive-sense RNA virus having seven distinct serotypes (A, Asia 1, C, O, SAT 1, SAT 2 and SAT 3) (17). FMD is endemic in many countries throughout the world, with serotype $\mathrm{O}$ having the highest prevalence, followed by serotype A (9). Early detection of the virus is critical to minimizing disease spread and the significant economic implications (12) resulting from the introduction of FMD into a country previously free of the disease. Diagnosis of FMD can be confounded by diseases with similar clinical signs ("look-alike" diseases), and by species where presentation of the disease is mild or indistinct (16). For the laboratory identification of FMDV, the Office International des Epizooties (OIE) recommends virus isolation (VI), antigen-ELISA (AgELISA), and RT-PCR with detection by agarose gel electrophoresis or in real-time using TaqMan ${ }^{\circledR}$ fluorogenic probes (15).

Real-time PCR is widely used by diagnostic laboratories, to complement or as a replacement for more traditional detection methods. Two independent real-time reverse transcription polymerase chain reaction (rRT-PCR) assays for FMD laboratory diagnosis target the ribosomal entry site of the $5^{\prime}$ untranslated region ( $5^{\prime}$ UTR) (30) and the viral RNA polymerase gene (3D) (4) on the highly variable FMDV genome. The 5'UTR and 3D rRT-PCR assays were initially compared prior to their implementation in Australia (3). A subsequent in-depth comparative evaluation (14) was conducted to further evaluate the effectiveness of these assays; demonstrating a higher diagnostic sensitivity of the rRT-PCR assays over VI and/or antigenELISA (35), particularly when both assays were used in combination. Both assays are used routinely in combination at the Food and Agriculture Organization of the United Nations, World 
Reference Laboratory (FAO WRL) for FMD. rRT-PCR assays have also been reported for the detection of other viruses which cause vesicular disease of livestock including swine vesicular disease (SVD) (29), vesicular stomatitis (VS) $(11,28)$ and vesicular exanthema of swine (VES) (31) or symptomatic look-alike diseases including bluetongue $(13,27,33)$, bovine viral diarrhea $(1,2,20,22,39)$, malignant catarrhal fever (37) and parapoxvirus (26).

Fluorescent probes for rRT-PCR detection have broad emission spectra which limit multiplexing capacity to the four or five discrete optical channels typically present in most commercial real-time PCR instruments. Therefore, simultaneous testing for FMDV and lookalike disease viruses by rRT-PCR would require many assays to be run in parallel, thereby increasing the demand on instrumentation and reagents which escalates costs. A single multiplexed screening test that simultaneously detects and differentiates FMDV from look-alike disease viruses would be desirable. Such a test could facilitate rapid and cost-effective screening of suspect FMD field samples for laboratory differential diagnosis, targeted FMD surveillance, or embedded foreign animal disease surveillance whilst conducting routine testing for endemic diseases.

Luminex xMAP technology is a multiplexed high-throughput detection system (38) with many applications for nucleic acid detection (6). The Luminex array offers up to 100 independent channels using microspheres $(5.6 \mu \mathrm{m})$ embedded with varying ratios of two fluorescent dyes. User-defined surface modifications can include oligonucleotides, antibodies, peptides or other macromolecules. Typically, a mixed suspension of functionalized microspheres is mixed with the sample to bind analytes which are then labeled with a fluorescent reporter and analyzed using a specialized flow-cytometer. The assay provides end-point detection with qualitative results by comparing fluorescence responses (median fluorescence intensity, MFI) of each microsphere 
class to cut-off values. Recent nucleic acid applications of the Luminex array include the detection and differentiation of Classical swine fever virus from other pestiviruses (5), human respiratory viruses $(18,19,21,23)$, human papillomavirus $(10,32)$ and human influenza A virus typing (40).

This report describes a novel multiplexed RT-PCR microsphere array assay for the differential detection of FMDV from look-alike disease viruses. The development, optimization and analytical evaluation of this multiplex assay will be reported separately. The primary purpose of this study was to evaluate the diagnostic performance of the mRT-PCR assay for the detection of FMDV using a panel of suspect field samples. The diagnostic sensitivities of the $3 \mathrm{D}$ and 5 'UTR FMDV assays in mRT-PCR format were compared to rRT-PCR using VI with Ag-ELISA as the reference method. The detection of look-alike diseases in suspect FMD field samples is also reported. 


\section{Materials and Methods}

\subsection{Samples}

The panel comprised epithelia (true positive $n=213$, true negative $n=34$ ) from suspect field cases of FMD submitted from 65 countries to the FAO WRL for FMD between 1965 and 2006 and included representatives of all seven serotypes of FMDV. In addition, 39 samples of true negative tongue epithelial were collected from healthy cattle at a UK abattoir. All sample testing and reference measurements were conducted at the FAO WRL for FMD. Epithelia were ground and suspended to generate $\mathrm{a} \sim 10 \% \mathrm{w} / \mathrm{v}$ suspension in phosphate buffer $(0.04 \mathrm{M}, \mathrm{pH} 7.6)$. The epithelial suspensions (ES) were centrifuged, the supernatant collected, then stored at $-80^{\circ} \mathrm{C}$. FMDV serotype was determined by conducting an antigen-ELISA (8) on the original ES or after viral propagation in cell culture. Samples of look-alike viruses from the FAO WRL for FMD collection included SVDV, VESV, San Miguel sea lion virus (SMSV), caliciviruses isolated from a variety of species (including cetacean, bovine, feline, reptile, skunk) and vesicular stomatitis virus (VSV).

\subsection{Nucleic acid extraction}

Total nucleic acid was extracted from each ES by an automated procedure using a MagNA Pure LC (Roche, UK) as previously described (14, 35). Extracted samples (40 $\mu \mathrm{L})$ were aliquoted $(3 \times 13 \mu \mathrm{L})$, stored at $-80^{\circ} \mathrm{C}$ and thawed once just before use.

\section{3. rRT-PCR}

Previously reported protocols for the individual 3D (4) and 5'UTR (34) rRT-PCR assays were modified for use in this study. Briefly, $25 \mu 1$ reaction mixes (SuperScript ${ }^{\mathrm{TM}}$ III Platinum ${ }^{\circledR}$ OneStep qRT-PCR System (Invitrogen)) containing 20 pmol of each primer, 7.5 pmol of duallabelled TaqMan ${ }^{\circledR}$ probe and $5 \mu$ l total nucleic acid were prepared in an optical reaction plate 
(Stratagene, Amsterdam, The Netherlands). For both targets, RT-PCR amplification was performed in an Mx4000 Multiplex Quantitative PCR System (Stratagene) as described previously (34).

\section{4. mRT-PCR assay design}

A schematic depiction of the mRT-PCR assay is shown in Figure 1. The RT-PCR uses eighteen biotinylated forward and unmodified reverse primer sets (17 for detection, 1 serves as a control).

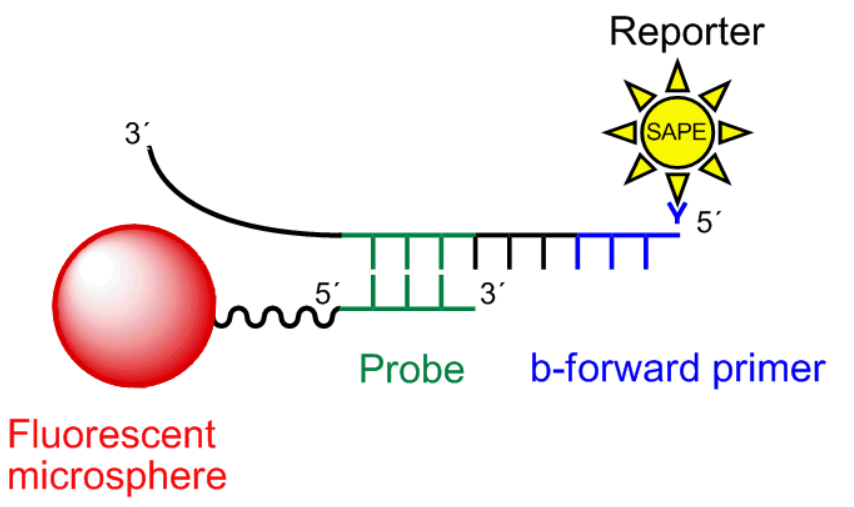

Figure 1: Schematic of the multiplex RT-PCR assay. In the presence of target nucleic acid, the biotinylated forward primer is extended during the PCR. The PCR product is hybridized to the microsphere array, whereby the extended forward primer binds to the complementary probe-labeled microsphere. The complex is labeled with fluorescent reporter (SAPE) then analyzed using a Bio-Plex flow cytometer. The fluorescence (570 $\mathrm{nm}$ ) of bound reporter molecules is measured, and the median fluorescence intensity is calculated for each microsphere class, then compared to a cut-off to indicate the presence or absence of a target nucleic acid sequence in a sample.

The sequences that comprise the multiplex assay are shown Table 1 . The multiplex assay was designed to detect and differentiate FMDV from SVDV, VESV, Bovine Viral Diarrhea Virus (BVDV), Bluetongue Virus (BTV), Parapox viruses (Orf virus, pseudocowpox virus, and bovine papular stomatitis virus), and Bovine Herpes Virus-1 (BHV-1). Primer-probe sequences for FMDV $(4,30)$ and $\operatorname{BVDV}(7,22)$ were based on the work of others and adapted to the current multiplex format. All other sequences were designed at Lawrence Livermore National 
Laboratory (LLNL) using an approach that has previously been described (36). Additional computational analyses were performed to ensure specificity and reliability against all available data, including a BLAST-based comparison of each primer-probe set as a triplet against all sequences in GenBank to identify the targets that are predicted to produce a PCR or TaqMan reaction at $57^{\circ} \mathrm{C}$ for primer annealing and $67^{\circ} \mathrm{C}$ for probe annealing, where temperatures are derived from Primer 3 oligo $\mathrm{T}_{M}$ calculations. Optimal candidate primer-probe sets were forwarded to the bench screening phase for further down-selection. Amplicon sizes ranged from $95-349$ bp. 
Table 1: Primer and probe sequences of the multiplex RT-PCR assay.

\begin{tabular}{|c|c|c|}
\hline $\begin{array}{l}\text { Assay } \\
\text { name }\end{array}$ & $\begin{array}{l}\text { Forward Primer }\left(5^{\prime} \rightarrow 3^{\prime}\right) \\
\text { Reverse Primer }\left(5^{\prime} \rightarrow 3^{\prime}\right)\end{array}$ & Probe $\left(5^{\prime} \rightarrow 3^{\prime}\right)$ \\
\hline BHV 1 & $\begin{array}{l}\text { GFGCCAGCCGCGFAAAAG } \\
\text { GACGACTCCGGGCTCTTTT }\end{array}$ & TCCTGGTTCCAGAGCGCTAACATGGAG \\
\hline$\overline{\mathrm{BHV}} 2$ & $\begin{array}{l}\text { TGAGGCCҒATGTATGGGCAGFT } \\
\text { GCGCGCCAAACATAAGTAAA }\end{array}$ & AAATAACACGGTGTGCACTTAAATAAGATTCGCG \\
\hline BTV 1 & $\begin{array}{l}\text { GCACCCҒATATGTTҒCCAGACCA } \\
\text { CAGCTAACTCTTCAGCCACACG }\end{array}$ & CTAACTCGTGGGCCAATCATCATCTTCTGT \\
\hline BTV 2 & $\begin{array}{l}\text { AGAATFCAGGAFGGGCAGGA } \\
\text { GCACAATTCCCATCCCCTTA }\end{array}$ & CCATCACACCATTATACTGTACCCGCGTAGC \\
\hline BVDV & $\begin{array}{l}\text { GGTAGTCGFCAGTGGTFCGAC } \\
\text { CATGTGCCATGTACAGCAGAGAT }\end{array}$ & CCTCGTCCACGTGGCATCTCGAG \\
\hline $\begin{array}{l}\text { FMDV } \\
3 \mathrm{D}\end{array}$ & $\begin{array}{l}\text { ACTGGGFTTTACAAACCFGTGA } \\
\text { GCGAGTCCTGCCACGGA }\end{array}$ & GTCCCACGGCGTGCAAAGGA \\
\hline $\begin{array}{l}\text { FMDV } \\
\text { 5'UTR }\end{array}$ & $\begin{array}{l}\text { CACYTYAAGRFGACAYTGRTACFGGTAC } \\
\text { CAGATYCCRAGTGWCICITGTTA }\end{array}$ & CCTCGGGGTACCTGAAGGGCATCC \\
\hline$\overline{P P O X} 1$ & $\begin{array}{l}\text { GCAGAFGCGCTCCFGGTT } \\
\text { GCACCTCTGCTGCTGCAA }\end{array}$ & CCGACTCCGACGTGGAGAACGTG \\
\hline PPOX 2 & $\begin{array}{l}\text { GATGGCCGFGCAGCFCTT } \\
\text { CGTACAAGATCACGGCCAACT }\end{array}$ & TGTACGGGCTCATGGGCTTCCG \\
\hline PPOX 3 & $\begin{array}{l}\text { GCAGCAGFGCACCACGFAGT } \\
\text { CGCTGAACCCGTACATCCT }\end{array}$ & GACTTCGAGGCGGACAACAAGCG \\
\hline SVDV 1 & $\begin{array}{l}\text { CAGGAFAATTTCTFCCAAGGGC } \\
\text { ACGTGAACATTTCGAGCTTCC }\end{array}$ & TGCATTGTGTCTGATGGTACAACTTGTGACG \\
\hline SVDV 2 & $\begin{array}{l}\text { GACTTGFTGTGGCFGGAGGA } \\
\text { CAGCGCCATGGTGAGGTAG }\end{array}$ & TGACCGTAATGAGGTCATCGTGATTTCTCAC \\
\hline SVDV 3 & $\begin{array}{l}\text { GACAAAGFGGCCAAGGGAAA } \\
\text { CACGTAAACCACACTGGGCT }\end{array}$ & CTGGCGTCATAGCCTGAATAGTCAAACGCTA \\
\hline VESV 1 & $\begin{array}{l}\text { GCCTFCTCCCTFCCCAAAA } \\
\text { TGAAGGAATGGTTCCGTCAGT }\end{array}$ & CATCATCGTTGATAACCTTAGATGTGCAATTTGG \\
\hline VESV 2 & $\begin{array}{l}\text { GGGAAFGAGGTGTGCAFCATT } \\
\text { CACGTCTTGATGTTGGCTTGAC }\end{array}$ & AAATTGGCATAATCAACCTTGTCAGATGAGTCG \\
\hline VESV 3 & $\begin{array}{l}\text { GGTCGCҒCTCACTGATGAFGAGTA } \\
\text { GGTGTTATCAGCACCCATTGC }\end{array}$ & GCTCGGTGCCTGAGTTGGAGGAAG \\
\hline VESV 4 & $\begin{array}{l}\text { ACCACCFCTGGAAACATCFATGG } \\
\text { TTTGTGCACGTGTCACGAAT }\end{array}$ & CGGGACGGGCATTTGTCACCA \\
\hline$\overline{\mathrm{FC}}$ & N/A & CAAAGFGGGAGACGTCGҒTG \\
\hline $\mathrm{IC}$ & $\mathrm{N} / \mathrm{A}$ & CAAAGTGGGAGACGTCGTTG-Cy3 \\
\hline $\mathrm{NC}$ & N/A & CAAAGTGGGAGACGTCGTTG \\
\hline
\end{tabular}

BHV = bovine herpes virus-1, PPOX = parapox virus complex, FMDV = foot-and-mouth disease virus, BVDV = Bovine Viral Diarrhea Virus, BTV = bluetongue virus, SVDV $=$ swine vesicular disease virus, $\mathrm{VESV}=$ vesicular exanthema of swine virus, $\mathrm{NC}=$ negative control, $\mathrm{FC}=$ fluorescence control, $\mathrm{IC}=$ instrument control, $\mathrm{Cy} 3=$ fluorescent cyanine dye, $\mathrm{Y}=$ pyrimidines $(\mathrm{C} / \mathrm{T}), \mathrm{R}=$ purines $(\mathrm{A} / \mathrm{G}), \mathrm{W}=$ weak 2-bonds $(\mathrm{A} / \mathrm{T}), \mathrm{I}=$ inosine (universal base). $\mathrm{F}=$ an internal biotinylated dT. All forward primers also include biotinylation at the $5^{\prime}$ terminus. All probes contain an amine attached to the $5^{\prime}$ terminus with a carbon 6 and internal spacer 18 . N/A = not applicable. 


\section{5. $\mathrm{mRT}$-PCR primers and probes}

All oligonucleotides used for mRT-PCR were synthesized by Integrated DNA Technologies (IDT, Coralville, IA) and HPLC-purified. Forward primers were functionalized with $5^{\prime}$ and internal biotin moieties. Reverse primers were unmodified. Probes were $5^{\prime}$ amino C6-modified with an 18-atom hexaethyleneglycol spacer. Lyophilized probe was dissolved in 2-(Nmorphilino)ethanesulfonic acid (MES) to yield a stock concentration of $1 \mathrm{mM}$. Lyophilized forward and reverse primers were dissolved in TE buffer to yield a stock concentration of $1 \mathrm{mM}$. Working dilutions were prepared from the stock solutions as required.

\subsection{Coupling of probe oligonucleotides to microspheres} xMAP ${ }^{\circledR}$ Multi-Analyte $\mathrm{COOH}$ Microspheres (Luminex Corp., Austin, TX) were covalently coupled to probe oligonucleotides using carbodiimide activation based on the manufacturer's protocol. Briefly, stock microspheres $\left(1 \mathrm{~mL}, 1.25 \times 10^{7}\right.$ microspheres) were vortexed for $30 \mathrm{~s}$, sonicated for $60 \mathrm{~s}$, centrifuged at $8000 \times \mathrm{g}$ for $5 \mathrm{~min}$ and the supernatant removed. The microspheres were then resuspended in MES $(50 \mu \mathrm{L}, 0.1 \mathrm{M}, \mathrm{pH} 4.5)$, vortexed and sonicated. Probe $(10 \mu \mathrm{L}, 50 \mathrm{mM}$ in MES) was added and the mixture vortexed. An aqueous solution of $N$ (3-dimethylaminopropyl)- $N^{\prime}$-ethylcarbodiimide hydrochloride (EDC; $5 \mu \mathrm{L}, 10 \mathrm{mg} / \mathrm{mL}$ ) was added, vortexed, then gently agitated for $30 \mathrm{~min}$ in the dark. A second aliquot of EDC (5 $\mu \mathrm{L}, 10$ $\mathrm{mg} / \mathrm{mL})$ was added, vortexed, then gently agitated for $30 \mathrm{~min}$ in the dark. Tween $20(1 \mathrm{~mL}$, $0.02 \% \mathrm{v} / \mathrm{v}$ ) was added, vortexed, centrifuged, the supernatant removed, then repeated using SDS $(1 \mathrm{~mL}, 0.1 \% \mathrm{~m} / \mathrm{v})$ then TE buffer $(100 \mu \mathrm{L} 1 \mathrm{mM}$ Tris, $10 \mathrm{mM}$ EDTA, $\mathrm{pH}$ 7.4). The probeconjugated microspheres were resuspended in TE buffer $(250 \mu \mathrm{L})$, vortexed, then stored at $4^{\circ} \mathrm{C}$ in the dark. 


\subsection{Microsphere mixture}

A 21-plex microsphere suspension was prepared by combining individual stock suspensions $(9$ $\mu \mathrm{L} /$ class) with Tris-NaCl buffer $(3 \mathrm{~mL})$. The mixture was vortexed then enumerated using the Bio-Plex, targeting approximately 150 microspheres counts per class in $40 \mathrm{~s}$. If required, additional microspheres from the individual stocks were added to ensure the concentrations of all classes were approximately equal.

\section{8. mRT-PCR amplification.}

Each field sample was analyzed in duplicate by the multiplex assay. Amplification was performed using a one-step RT-PCR kit (SuperScript ${ }^{\mathrm{TM}}$ III One-Step RT-PCR System with Platinum ${ }^{\circledR}$ Taq DNA Polymerase, Invitrogen). The reaction volume of $25 \mu \mathrm{L}$ was comprised of nuclease-free water $(0.95 \mu \mathrm{L})$, primer mix $(3.6 \mu \mathrm{L})$, SuperScript ${ }^{\mathrm{TM}}$ III $2 \mathrm{X}$ reaction mix $(12.5$ $\mu \mathrm{L}), \mathrm{MgSO}_{4}\left(0.95 \mu \mathrm{L}, 50 \mathrm{mM}\right.$, Invitrogen), SuperScript ${ }^{\mathrm{TM}} \mathrm{III} \mathrm{RT} /$ Platinum $^{\circledR}$ Taq Mix (1 $\left.\mu \mathrm{L}\right)$, internal control armored RNA (1uL, $\sim 100$ copies) and template $(5 \mu \mathrm{L})$. The internal control armored RNA was lysed by heating to $70^{\circ} \mathrm{C}$ for 4 min prior to addition to the mix. The final concentration of each primer and $\mathrm{MgSO}_{4}$ was $0.4 \mu \mathrm{M}$ and $3.5 \mathrm{mM}$, respectively. The RT-PCR thermal cycling protocol was $55^{\circ} \mathrm{C}$ for $30 \mathrm{~min}, 95^{\circ} \mathrm{C}$ for $2 \mathrm{~min}$, then 35 cycles of $95^{\circ} \mathrm{C}$ for $15 \mathrm{~s}$, $60^{\circ} \mathrm{C}$ for $30 \mathrm{~s}$, and $72^{\circ} \mathrm{C}$ for $15 \mathrm{~s}$, followed by $72^{\circ} \mathrm{C}$ for 2 min with a final $4^{\circ} \mathrm{C}$ hold.

\subsection{Microsphere array hybridization}

A wash-assay format was adopted to reduce variability of the response caused by non-specific hybridization of PCR products and fluorescent label. In a 96-well plate, RT-PCR product ( $1 \mu \mathrm{L})$ was added to a mixed suspension of probe-conjugated microspheres $(22 \mu \mathrm{L})$ then placed in a thermal cycler and subjected to $95^{\circ} \mathrm{C}$ for $2 \mathrm{~min}, 55^{\circ} \mathrm{C}$ for $5 \mathrm{~min}$, followed by a $4^{\circ} \mathrm{C}$ hold. Tris$\mathrm{NaCl}$ buffer $(100 \mu \mathrm{L}, 0.1 \mathrm{M}$ Tris, $0.2 \mathrm{M} \mathrm{NaCl}, 0.05 \% \mathrm{v} / \mathrm{v}$ Triton $\mathrm{X}-100, \mathrm{pH} 8.0$, Teknova) was 
added and the suspension was transferred to a 96-well vacuum filter plate (MABVN 1250 Multiscreen Filter Plate, Millipore). The suspension was vacuum-aspirated, and washed twice with Tris-NaCl buffer $(2 \times 100 \mu \mathrm{L})$. Stock streptavidin phycoerythrin (SAPE, $1 \mathrm{mg} / \mathrm{mL}$, Caltag Laboratories) was diluted with Tris- $\mathrm{NaCl}$ to a working concentration of $3 \mu \mathrm{g} / \mathrm{mL}$. SAPE (60 $\mu \mathrm{L}$, $3 \mu \mathrm{g} / \mathrm{mL}$ ) was added then incubated in the dark for $5 \mathrm{~min}$. The suspension was vacuumaspirated, washed once with Tris- $\mathrm{NaCl}(100 \mu \mathrm{L})$, re-suspended in Tris-NaCl $(100 \mu \mathrm{L})$ then transferred to a 96-well round bottom plate for fluorescent detection. Nucleic acid extraction, PCR reaction assembly and PCR amplification were conducted in separate rooms. Likewise, hybridization and Bio-Plex detection were performed together in a separate room to minimize the likelihood of PCR contamination by amplicons.

\subsection{0. $\quad$ mRT-PCR detection}

Fluorescence detection of the processed microsphere suspension array was achieved using a Bio-Plex Workstation (Bio-Rad, CA) set to count a minimum of 100 events per microsphere class in a $50 \mu \mathrm{L}$ Bio-Plex sample volume. The Bio-Plex Workstation is a specialized dual-laser flow cytometer integrated with $\mathrm{XY}$ microplate platform configured to analyze Luminex xMAP® microspheres in a 96-well plate format. The reporter PMT voltage was calibrated on the low setting with background subtraction enabled. The Bio-Plex workstation was validated and calibrated per the manufacturer's instructions. The resolution of the MFI was 0.5 units for all channels.

\subsection{1. mRT-PCR assay controls}

The multiplex assay incorporates four control channels integral to each reaction that are used to verify assay integrity. The negative control (NC) is a microsphere conjugated to Thermotoga maratima-derived oligonucleotide sequence (MT-7) that serves as a non-specific binding control 
in the multiplex PCR assay, and its response should remain consistently low (MFI $\leq 80)$. The fluorescence control (FC), biotinylated MT-7, confirms that fluorescent labeling with SAPE occurred and should exhibit a high response (MFI >1000). The instrument control (IC) comprises a Cy3-labeled MT-7 conjugate. As Cy3 and SAPE have similar fluorescence excitation and emission wavelengths, the IC confirms proper function of the reporter optics within the Bio-Plex flow cytometer (MFI $>500)$. Armored RNA served as an end-to-end amplification control (AC) to reduce the probability of false negative and is utilized at low concentrations (100 copies/reaction) to generate a low-level response (MFI $\geq 20$ ) which minimizes its competition with detection channels. The armored RNA (XenoRNA-01, Ambion, Austin, TX) is a proprietary 1070 nucleotide RNA transcript consisting of unique nucleotide sequences that possess no significant homology to the current annotated sequences in commonly used sequence databases including NCBI, Affymetrix, and Rosetta. Primers and probe-labeled microsphere for the AC are included in the multiplex primer mix and microsphere suspension, respectively.

\subsection{2. mRT-PCR assay integrity}

Minimum bead count quota and control channel responses were used to verify the integrity of the detection channel responses which minimizes the likelihood of false positives and falsenegative results caused by operator error, instrument malfunction, non-specific hybridization, or PCR inhibition. A flowchart summarizing the algorithm is shown in Figure 2. If a low bead count for any control channel occurred, then all results for that sample were considered invalid. The responses of all detection channels are checked against pre-established cut-offs then identified as mRT-PCR positive, negative or inconclusive. For each sample, the MFI of each control bead class was checked against a cut-off value. A given result was considered invalid 
when the MFI value of the IC, NC or FC controls was out of range, or when both the response of the $\mathrm{AC}$ was $<20$ and no detection channels exceeded cut-off. Results were considered valid when the $\mathrm{AC}$ was $<20$ and any detection channel exceeded cut-off. The AC response can be diminished by a strong positive response on a detection channel caused by competition in the RT-PCR reaction. If the responses of all control channels are acceptable, the number of beads counted for control and detection channels are checked ( $\geq 40$ beads per channel). A low bead count on a given detection channel was considered an invalid result for the channel in question.

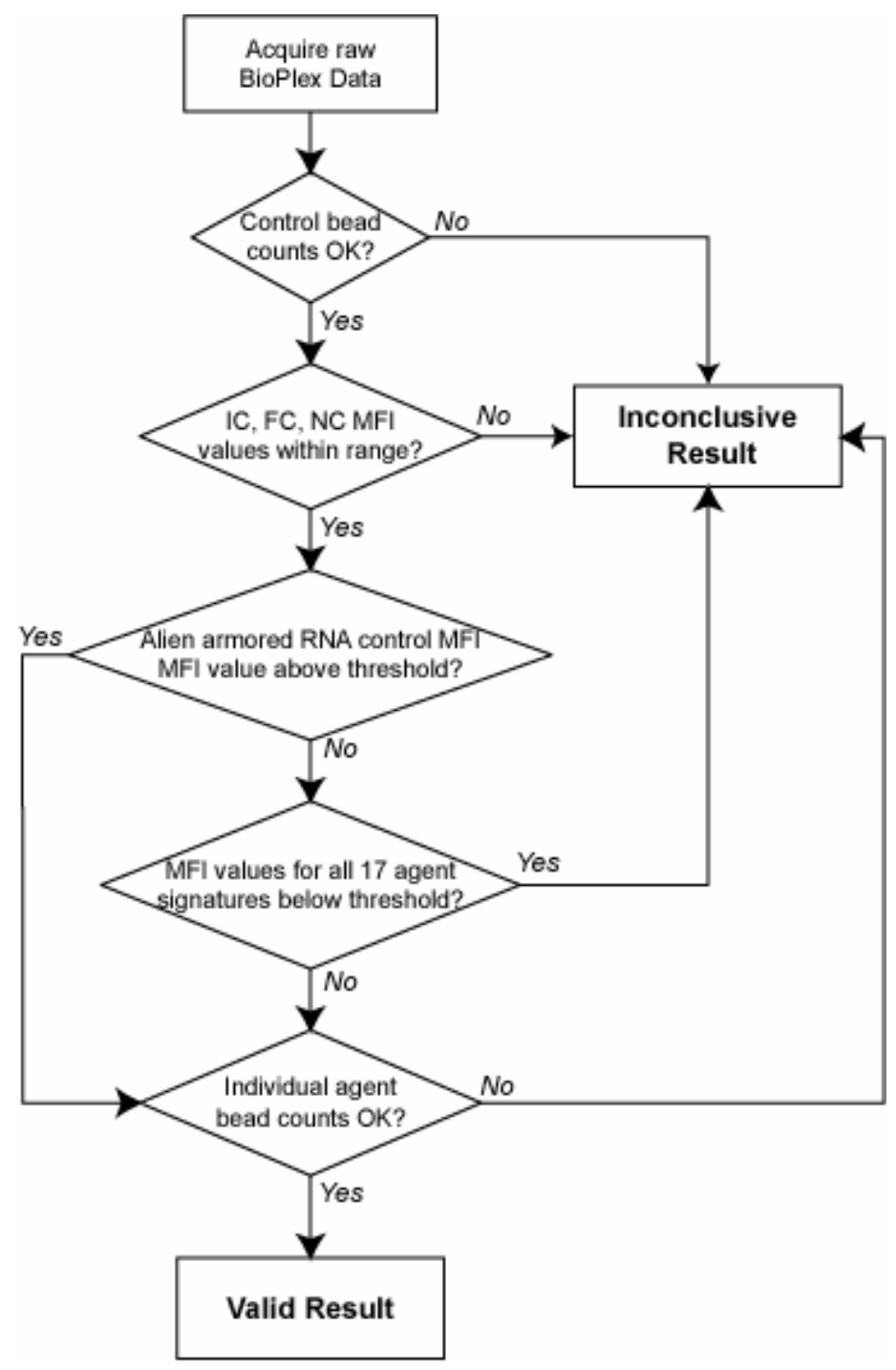

Figure 2: Algorithm used to verify mRT-PCR assay integrity. 


\subsection{Data analysis}

Raw data exported from the Bio-Plex instrument were imported into MATLAB (MathWorks) then analyzed using Microsoft Excel. If at least one result from a duplicate sample analysis exceeded cut-off, the sample was assigned as mRT-PCR positive. Receiver Operating Characteristic (ROC) plots (24) were generated using a custom MATLAB program. Published guidelines (25) were followed for the calculations of diagnostic test accuracy and statistical methods to quantify uncertainty.

\subsection{Cut-off values}

The mRT-PCR responses for this assay are typically non-Gaussian and therefore nonparametric methods were used to determine cut-offs. Each channel in the multiplex has a distinct distribution of responses to true negative samples and therefore each is assigned its own cut-off value. For each detection channel of the mRT-PCR assay, the responses to true negative samples were ranked according to magnitude, then cut-off values were identified as the response (MFI value) which gave a false positive rate closest to $5 \%$ (without exceeding $5 \%$ ), corresponding to a diagnostic specificity of at least $95 \%$ (3D MFI $\geq 6.5,5^{\prime} \mathrm{UTR}$ MFI $\geq 5.5$ ). Cut-offs for all mRTPCR detection channels are shown in Table 2. For rRT-PCR, the cut-off was $\mathrm{Ct} \leq 32$ for both $3 \mathrm{D}$ and 5'UTR assays (34). 
Table 2: Cut-offs for each detection channel of the multiplex RT-PCR assay.

\begin{tabular}{lc}
\hline $\begin{array}{l}\text { Detection } \\
\text { channel }\end{array}$ & $\begin{array}{c}\text { Cut-off } \\
\text { (MFI) }\end{array}$ \\
\hline BHV-1 & 7.5 \\
BHV-2 & 5.5 \\
PPOX-1 & 7.5 \\
PPOX-2 & 316 \\
PPOX-3 & 9.5 \\
FMDV 3D & 6.5 \\
FMDV 5'UTR & 5.5 \\
BVD & 6.5 \\
BTV-1 & 6.5 \\
BTV-2 & 6.5 \\
SVD-1 & 7.5 \\
SVD-2 & 8.5 \\
SVD-3 & 10.5 \\
VESV-1 & 6.5 \\
VESV-2 & 18.5 \\
VESV-3 & 18 \\
VESV-4 & 22.5 \\
\hline
\end{tabular}




\section{Results}

\subsection{Clinical sample validation.}

Receiver Operating Characteristic (ROC) plots were constructed to compare the diagnostic performance of the 3D and 5'UTR assays in rRT-PCR and mRT-PCR formats (Figure 3).

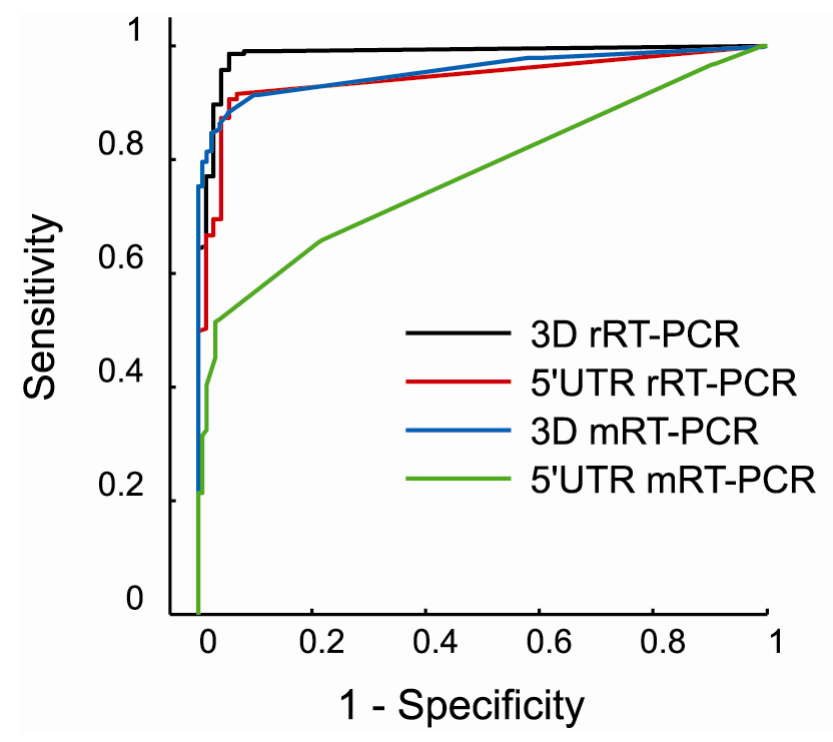

Figure 3: Receiver Operating Characteristic (ROC) plots for the RNA polymerase (3D) and the 5'untranslated region (5'UTR) assays in singleplex real-time reverse transcriptase PCR (rRT-PCR) and multiplexed reverse transcriptase polymerase chain reaction (mRTPCR) formats. True positive samples $(n=213)$ representative of all FMDV serotypes and true negative samples $(n=74)$ were analyzed. The area under the curves are; $3 \mathrm{D}$ rRTPCR (0.985), 5'UTR rRT-PCR (0.942), 3D mRT-PCR (0.955) and 5'UTR mRT-PCR (0.773).

For the purpose of this evaluation, VI with Ag-ELISA served as the reference method and therefore assigned samples as true negative or true positive, with the caveat that rRT-PCR is known to detect FMDV in some samples considered negative by VI with Antigen-ELISA (35). Each plot shows the true positive fraction (TPF; sensitivity) versus the false positive fraction (FPF; 1-specificity) over the entire range of cut-off values. The ROC plots indicate that the 3D and 5'UTR assays in mRT-PCR format lost some ability to distinguish between true negative 
and true positive samples, as compared to rRT-PCR. The associated areas under each ROC curve also indicate the level of test performance in the absence of a cut-off value. Transfer to the multiplex format had the greatest effect upon the 5'UTR assay where the area under the curve was reduced to 0.773 in comparison to 0.942 for the rRT-PCR format. In contrast, the effect upon the 3D assay was less apparent: 0.955 and 0.985 for the mRT-PCR and rRT-PCR formats respectively. The ROC plots were generated using 3D and 5'UTR assay results independently. In practice, 3D and 5'UTR assay results would be used in combination, an intrinsic feature of the mRT-PCR format. The trade-off between TPF and FPF shown by ROC plots can be used to inform cut-off selection. The cut-off value for all detection channels was determined from the mRT-PCR response to true negative samples $(n=74)$ using a specificity of $95 \%$.

Table 2 summarizes the performance metrics of the 3D and 5'UTR assays when used independently or in combination for both formats. Results are presented according to serotype then summarized for all serotypes. In some cases, the rRT-PCR response for true positive samples $\left(3 D ; n=5,5^{\prime} U T R ; n=9\right)$ and true negative samples $\left(3 D ; n=5,5^{\prime} U T R ; n=2\right)$ yielded $C t$ values that were beyond the cut-off. In practice, these samples would be considered weak rRTPCR positives and retested. 
Table 3: Performance metrics for the 3D and 5'UTR FMDV assays in rRT PCR and mRTPCR formats using independent or combined results.

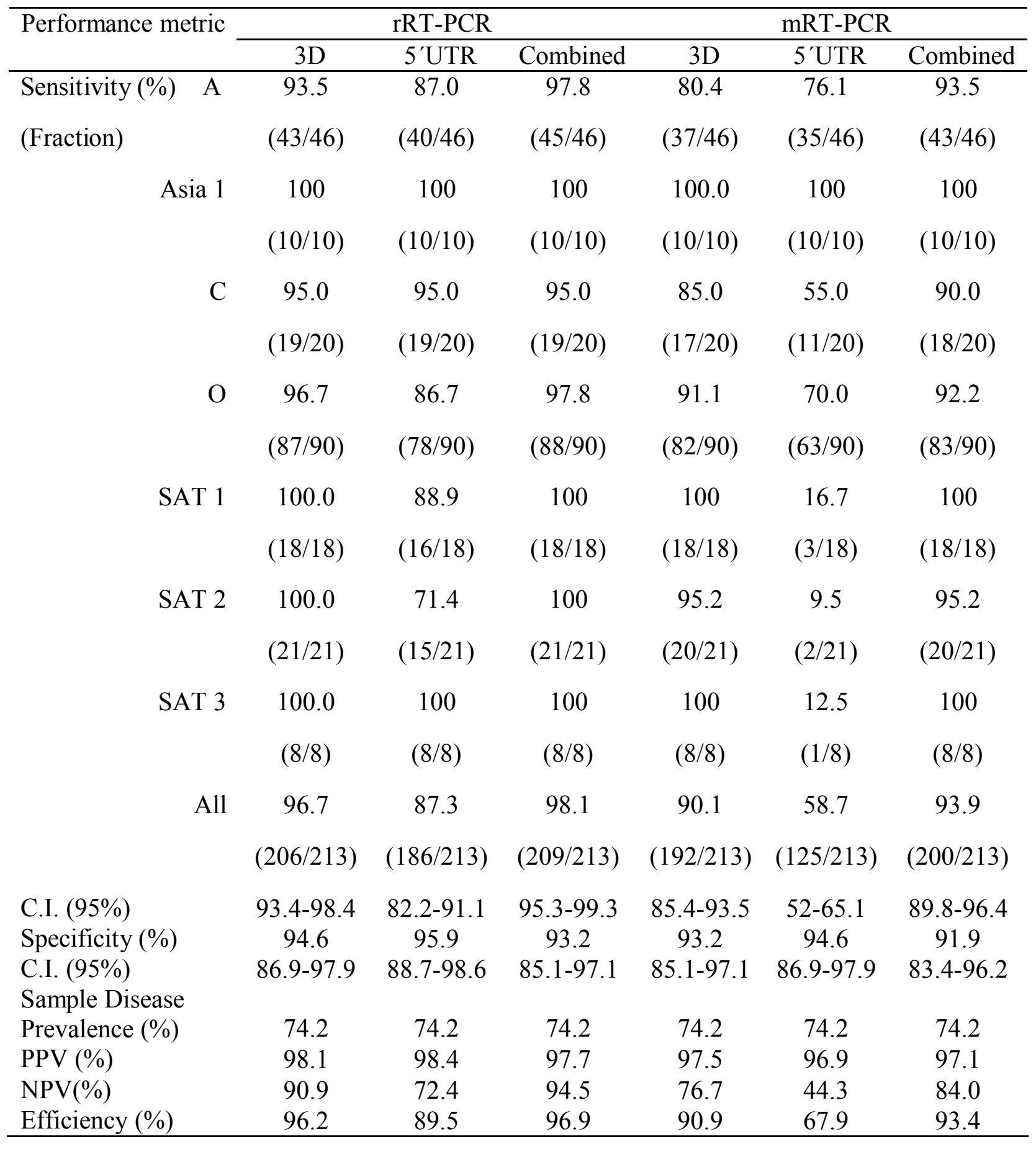

Sensitivity is the fraction of the 213 true positive epithelial tissue samples (subjected to both multiplex RT-PCR and rRT-PCR assays) that are assigned as FMDV-positive by the indicated assay. C.I. Confidence Interval, PPV Positive Predictive Value, NPV Negative Predictive Value. 
Table 3 shows a three-way comparison of mRT-PCR and rRT-PCR against the reference method using the combined 3D and 5'UTR assay results.

Table 4: 3-Way comparison table for the combined results of 3D and 5'UTR assays in rRT-PCR and mRT-PCR formats.

\begin{tabular}{ccccc}
\hline \multicolumn{2}{c}{ Method Result } & Total Samples & \multicolumn{2}{c}{ True Diagnosis } \\
\cline { 5 - 5 } Combined & Combined & & Positive & Negative \\
\cline { 5 - 5 } rRT-PCR & mRT-PCR & & & \\
\hline Positive & Positive & 202 & 200 & 2 \\
Positive & Negative & 12 & 9 & 3 \\
Negative & Positive & 4 & 0 & 4 \\
Negative & Negative & 69 & 4 & 65 \\
Total & & 287 & 213 & 74 \\
\hline
\end{tabular}

The agreement between mRT-PCR and rRT-PCR for true positive samples was 95.8\% (204/213). Two samples classified as FMDV-negative by VI and Ag- ELISA tested positive by both formats (SYR 6/2002, LAO 16/2003). Similarly, three samples (SYR 7/2002, TUR 17/2002, BHU 5/2004) which were negative by VI and Ag-ELISA tested positive by rRT-PCR but were negative by mRT-PCR due to its higher LOD. These findings are consistent with earlier studies $(14,35)$ where higher analytical sensitivity of rRT-PCR enabled detection of FMDV in samples designated negative by VI and Ag-ELISA. Due to its higher LOD, the mRTPCR missed 9/209 positive samples detected by rRT-PCR. Four mRT-PCR false positives had MFI responses that were close to the cut-off which was defined using a specificity of $95 \%$. Four mRT-PCR and rRT-PCR false negatives were samples of FMDV serotype A (NIG 12/74), C 
(PHI 2/89) and $\mathrm{O}\left(\mathrm{O}_{1}\right.$ Manisa TUR 8/69, YEM 1/2001). However, the rRT-PCR did generate $\mathrm{Ct}$ responses for two of these samples including PHI $2 / 89$ (3D; 38.94, 5'UTR; 38.51) and $\mathrm{O}_{1}$ Manisa (3D; 32.71). As the Ct values were beyond the cut-off they would be considered weak rRT-PCR positives and retested. These false negatives which generated either weak or no responses in mRT-PCR and rRT-PCR formats were likely caused by mutations in the FMDV gene segments targeted by the 3D and 5'UTR assays. They could also be due to low amounts of virus present, particularly for $\mathrm{O}_{1}$ Manisa, which is a titrated sample used as a positive control in the diagnostic rRT-PCR that was deliberately set to be only weakly positive.

In addition to the 287 samples used to evaluate the mRT-PCR assay, eleven additional suspect FMDV field samples of undetermined serotype were analyzed. These samples were found to be negative by VI and Ag-ELISA but confirmed positive by combined 3D and 5'UTR rRT-PCR during a previous study. These samples were analyzed by the mRT-PCR assay, which detected 11/11 of these samples, demonstrating that the multiplex also detects FMDV in clinical samples that were most likely rendered non-viable for VI between collection and laboratory receipt.

\subsection{Limit of detection}

The limit of detection (LOD) of the 3D and 5'UTR assays in mRT-PCR and rRT-PCR formats were compared using serially diluted clinical samples of serotype O or SAT 2 (Figure 4). At the defined cut-off values, the mRT-PCR LOD was higher than rRT-PCR by approximately 5-625 times for the 3D assay, and 25-125 times for 5'UTR, depending on serotype. The higher LOD of the mRT-PCR therefore caused the loss of diagnostic performance evident in the ROC plots. Further assay optimization efforts are underway to improve the limits of detection of the 3D and 5'UTR assays in the mRT-PCR format. 

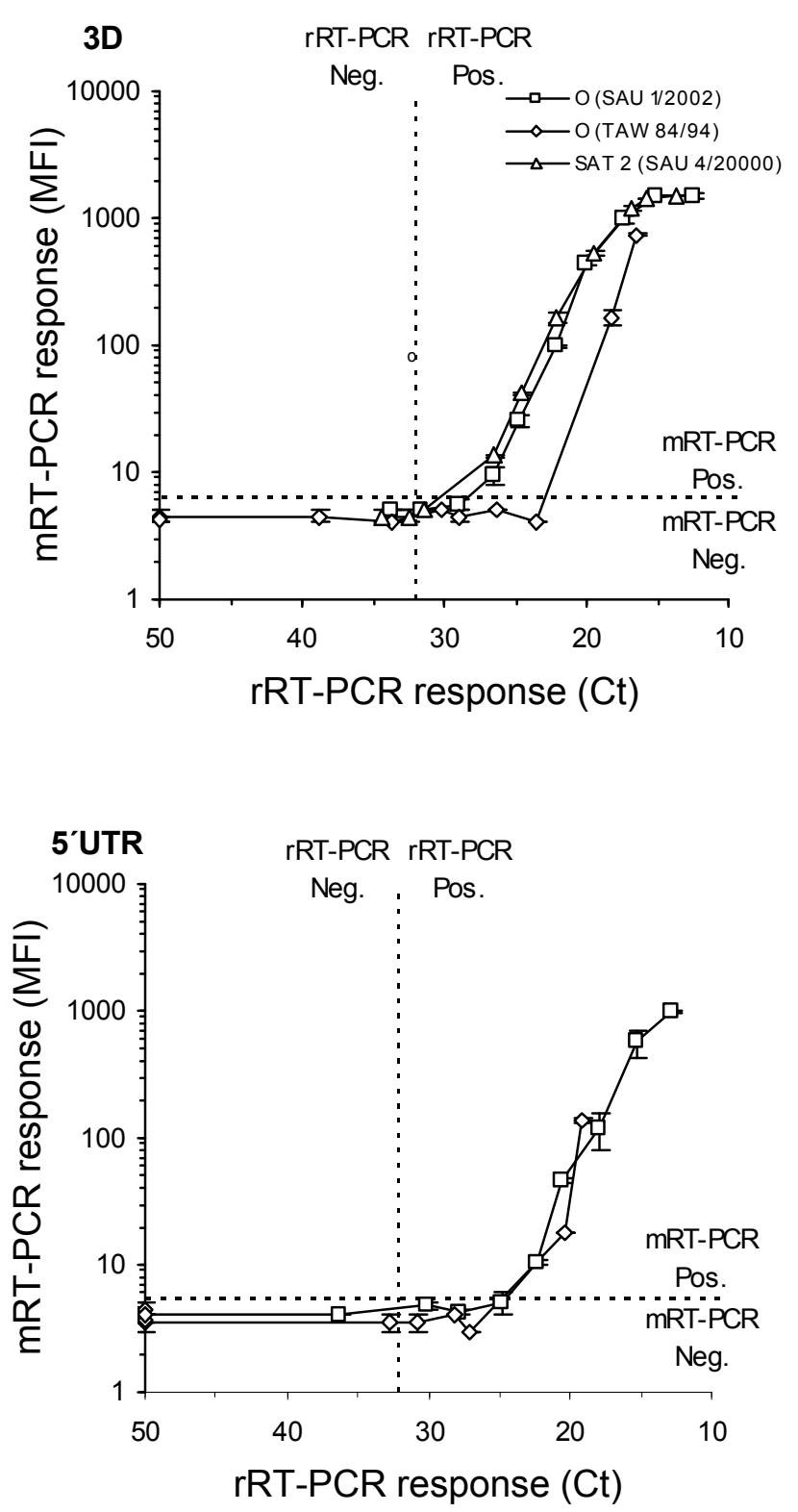

Figure 4: Comparison of the RNA polymerase (3D) and 5'untranslated region (5'UTR) assay responses in multiplex RT-PCR and singleplex rRT-PCR formats by consecutive 5fold serial dilutions of three different FMDV true positive epithelial suspension samples (undiluted to more dilute from right to left). The multiplex RT-PCR detection was less sensitive than singleplex rRT-PCR (approximately 5-625 times and 25-125 times, respectively for 3D and 5'UTR signatures). Cut-off values for $\mathrm{rRT}-\mathrm{PCR}(\mathrm{Ct} \leq 32)$ and mRT-PCR (3D MFI $\geq 6.5,5^{\prime}$ UTR $\geq 5.5$ ) are indicated by the vertical and horizontal dashed lines, respectively. The 5'UTR signature did not respond to the SAT 2 (SAU 4/2000) sample at any dilution in singleplex or multiplex formats and was omitted from the plot. Error bars indicate $\pm 1 \sigma$ of the mean $(n=2)$ response from the signature in mRTPCR format. For rRT-PCR each sample was analyzed in singlet $(n=1)$. 


\subsection{Differential detection}

Characterization of the diagnostic accuracy of the look-alike disease assays within the mRTPCR assay is ongoing and will be reported separately. The mRT-PCR assay was positive with three SVDV field samples (ITL 4/77, HKN 1/80, HKN 5/91), two VESV isolates (serotypes B51 and -H54), San Miguel sea lion virus (serotypes SMSV-7, -9, -10, -11 and -13) and cetacean calicivirus (CCV, Tur-1, dolphin). The mRT-PCR did not detect VESV -B1-34, other VESV serotypes including bovine (Bos-1 (Tillamook)), feline (A4), reptile (rattlesnake), and skunk, and VSV (serotype NJ 15/88 CP211634 and Indiana 1 subtype Ind 2 Maipu Argentina). Feline calicivirus is in a distinct genomic group from the other VESV viruses tested and was not expected to be detected by this assay. mRT-PCR identified look-alike disease viruses in four suspect FMD field samples that had previously been designated FMDV-negative by VI and rRTPCR (Figure 5). 

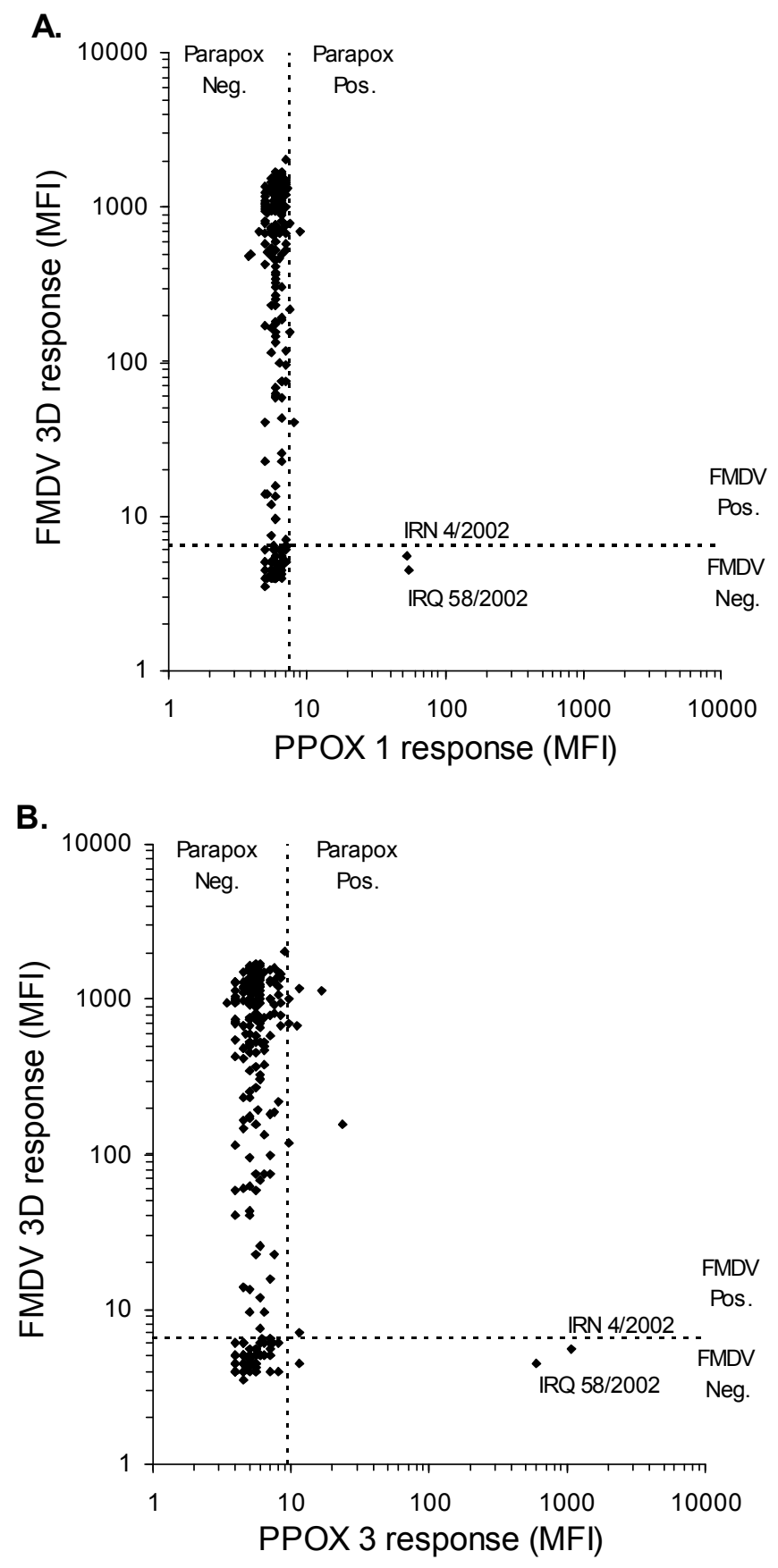


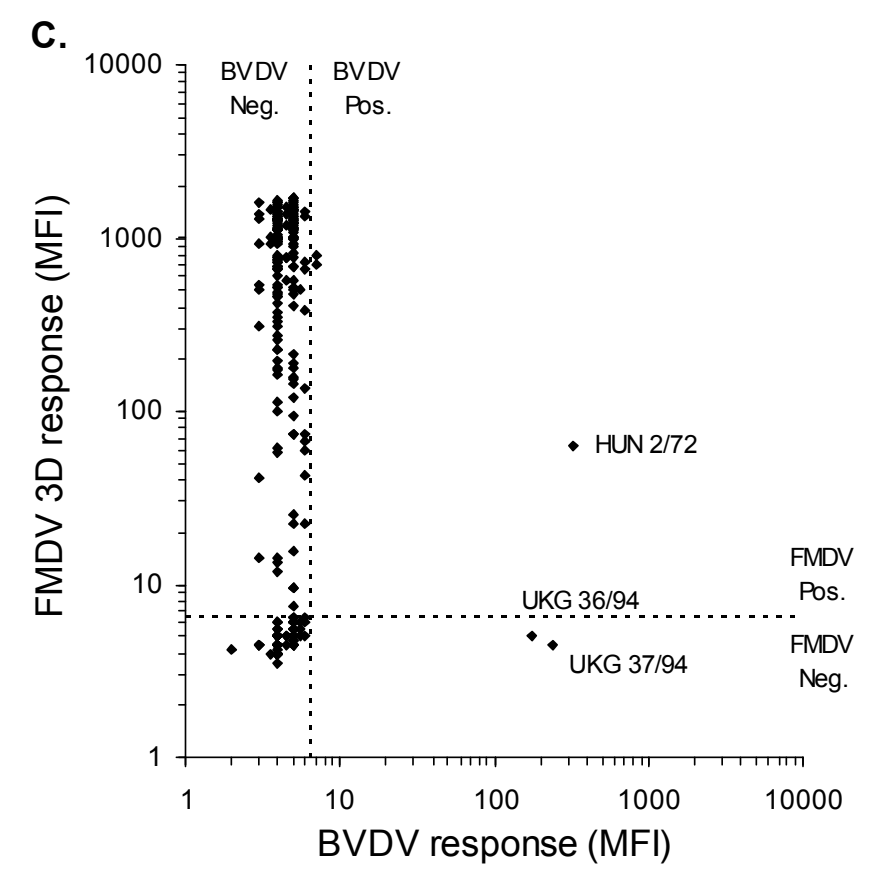

Figure 5: Multiplex RT-PCR assay identification of FMDV look-alike disease viruses in suspect FMDV clinical sample submissions. The mRT-PCR assay ruled out FMDV whilst simultaneously ruling in FMD look-alike disease viruses. A and B show the multiloci detection of parapox viruses. C shows BVDV detection in field samples from cattle (UKG 36/94, UKG 37/94) that were tested FMDV-negative by virus isolation and rRTPCR and the simultaneous detection of FMDV and BVDV (HUN 2/72). mRT-PCR cutoffs indicated by the vertical dashed lines were PPOX $1(\geq 7.5)$, PPOX $3(\geq 9.5)$ and BVDV ( $\geq 6.5)$. The horizontal dashed lines indicate the cut-off for FMDV 3D ( $\geq 6.5)$.

Two samples from cattle (IRN 4/2002, IRQ 58/2002) were mRT-PCR positive for parapoxvirus. The parapox-3 assay generated the strongest response, however all three assays exceeded their respective cut-off values for both samples. Two further cattle samples (UKG 36/94, UKG 37/94) were mRT-PCR positive for BVDV that were also confirmed FMDVnegative by all methods. The mRT-PCR simultaneously detected the co-infection of FMDV and BVDV in a FMDV true positive sample (HUN 2/72). The presence of BVDV, which causes a prevalent disease of cattle, did not mask the detection of FMDV. 
Cross-talk between detection channels was minimal, even at the relatively high concentrations of FMDV RNA in many of the field samples tested. A matrix of correlation coefficients for all channel pairings was calculated using the results of all FMDV true positive samples $(n=213)$. The correlation coefficients of the 3D and 5'UTR channels with other channels did not exceed 0.209 and 0.114 , respectively. 


\section{Discussion}

The mRT-PCR assay was able to detect FMDV at clinically relevant concentrations. The apparent concentration of FMDV in the clinical samples was relatively high as might be expected with vesicular epithelial tissue which, when infected, is rich in virus. The performance of mRT-PCR and singleplex rRT-PCRs was compared using VI and Ag-ELISA to define FMDV true positives and true negatives. Although VI and Ag-ELISA are established methods for the detection of FMDV, previous studies $(14,35)$ have demonstrated that rRT-PCR has higher diagnostic sensitivity and can detect virus in additional samples, which for the purposes of this study would be classified as "true" negatives. For the majority of true positive field samples, the 3D mRT-PCR response was saturated and grouped far from the cut-off. The 5'UTR mRT-PCR signal was generally lower and clustered on either side of the cut-off. The higher LOD of both assays in the mRT-PCR format may be caused by low-level non-specific interactions between primer sets that could reduce amplification efficiency. The primers used in the 5'UTR assay were not originally designed with multiplexing in mind. In order to recognize a wide range of FMDV isolates, the 5'UTR primers have a high degree of degeneracy (32-fold and 8-fold for the forward and reverse primers respectively) that could increase the likelihood of non-specific interactions with other primer sets in the multiplexed reaction mixture. Whilst primer probe sets incorporating degenerate nucleotides can offer broader coverage of highly-variable gene segments, further work is required to refine their design for multiplexed assays. Asymmetric PCR and multivariate optimization may lead to further improvements in the LODs of the 3D and 5'UTR mRT-PCR assays.

The 3D and 5'UTR assay responses had serotypic bias, a finding which agrees with earlier observations $(4,14)$. In mRT-PCR format, the 3D assay was less sensitive for A and C serotypes 
whereas the 5'UTR was less effective against SAT serotypes. For all serotypes collectively, the 3D assay was more sensitive than the 5'UTR within each format (rRT-PCR 3D 96.7\% vs. 5'UTR $87.3 \%$, mRT-PCR 3D 90.1\% vs. 5'UTR 58.7\%). In an earlier evaluation of the rRTPCR assays (14), the diagnostic sensitivity of the 3D (97.7\%) was found to be slightly higher than the 5'UTR assay (95.4\%). The diagnostic sensitivity increased when the results of the 3D and 5'UTR assays were used in combination. This is due to the "or" nature of the combination, whereby a single mRT-PCR positive result on the $3 \mathrm{D}$ or $5^{\prime} \mathrm{UTR}$ channel generates a combined mRT-PCR positive result. The diagnostic sensitivity of the combined mRT-PCR assay was 93.9\%, compared to $98.1 \%$ for combined rRT-PCR. The loss of diagnostic sensitivity from rRTPCR to mRT-PCR, due to higher limits of detection, was partially offset by the inherent ability of the multiplex assay to screen multiple loci simultaneously. Combined rRT-PCR only increased the diagnostic sensitivity by $1.4 \%$ compared to using the $3 \mathrm{D}$ rRT-PCR assay in isolation which could factor into the cost-benefit of conducting parallel assays. As the mRTPCR is a screening assay that would most likely be used in conjunction with confirmatory tests, potential users may be more tolerant of lower specificity in order to achieve higher sensitivity. The negative predictive value was also higher for combined assays, because of the "or" nature of the combined result as false negatives only occurred when both the 3D and 5 'UTR results agreed.

The differential detection of FMDV from look-alike disease viruses, which included ssRNA and dsDNA targets, was demonstrated by testing representative isolates of SVDV, VESV and VSV. For a diagnostic laboratory, this could produce time and cost savings, when compared to testing for each disease using singleplex rRT-PCR assays. For veterinarians, the mRT-PCR assay could increase confidence in a sample identified as FMDV-negative by simultaneously 
screening for the presence of look-alike diseases. For networks of veterinary diagnostic laboratories, an mRT-PCR assay could facilitate embedded foreign animal disease surveillance whilst conducting routine testing of endemic animal disease viruses. An inter-laboratory evaluation of this multiplex assay was recently conducted in fourteen US National Animal Health Laboratory Network laboratories; the results suggested the mRT-PCR technology could be operated successfully in this setting. The diagnostic performance evaluation for the look-alike disease assays in the mRT-PCR format is underway and will be reported separately.

The mRT-PCR format is compatible with procedures and instrumentation used for rRT-PCR. The use of a single method to prepare clinical samples for mRT-PCR and rRT-PCR analysis was demonstrated in this study. The mRT-PCR requires the post-processing of RT-PCR product to the microsphere array which takes $\sim 50$ min per 96 -well plate using manually operated multichannel pipettes. The 96-well plate format provides convenient interchangeability between manual and automated platforms. With this reagent set, the Bio-Plex flow cytometer analyzed each well in $\sim 40 \mathrm{~s}$, or $\sim 1 \mathrm{~h}$ per 96 -well plate. Although the diagnostic sensitivity of the mRTPCR for FMDV detection is slightly lower than singleplex rRT-PCR, it provides significantly more diagnostic information. With 17 detection channels for seven different viruses, the current prototype panel generates 1632 individual assay results per 96-well plate. The microsphere suspension array is a versatile platform compatible with many different types of diagnostic tests, including immunological and serological assays which could increase its utility within a veterinary diagnostic laboratory, not only for outbreak response and recovery but also for routine testing for endemic diseases. The inherent flexibility of the Luminex array also enables the composition of a given multiplex assay to be altered by simply adding or removing detection channels. Refinements to the first version of the mRT-PCR assay described herein are currently 
underway, including the development of two species-specific panels for more comprehensive coverage. These new panels incorporate additional assays for other FMDV look-alike diseases. The bovine-specific panel incorporates assays for FMD, Malignant Catarrhal Fever (MCF), Rinderpest, Bluetongue, BHV-1, BVD, Parapox and VS. The porcine-specific panel includes assays for FMD, SVD, VES, VS and Porcine Reproductive and Respiratory Syndrome (PRRS). 


\section{Acknowledgments}

This work was performed under the auspices of the U.S. Department of Energy by the University of California Lawrence Livermore National Laboratory under Contract No. W-7405Eng-48. It was funded by the Department of Homeland Security (DHS) Science and Technology Directorate, award (HSHQDC-06-X-00277) and UK DEFRA project SE1121. The material presented represents the position of the authors and not necessarily that of DHS. 


\section{References}

1. Baxi, M., D. McRae, S. Baxi, I. Greiser-Wilke, S. Vilcek, K. Amoako, and D. Deregt. 2006. A one-step multiplex real-time RT-PCR for detection and typing of bovine viral diarrhea viruses. Vet. Microbiol. 116:37-44.

2. Bhudevi, B., and D. Weinstock. 2001. Fluorogenic RT-PCR assay (TaqMan) for detection and classification of bovine viral diarrhea virus. Vet. Microbiol. 83:1-10.

3. Boyle, D. B., T. Taylor, and M. Cardoso. 2004. Implementation in Australia of molecular diagnostic techniques for the rapid detection of foot and mouth disease virus. Aust. Vet. J. 82:421-425.

4. Callahan, J. D., F. Brown, F. A. Csorio, J. H. Sur, E. Kramer, G. W. Long, J. Lubroth, S. J. Ellis, K. S. Shoulars, K. L. Gaffney, D. L. Rock, and W. M. Nelson. 2002. Use of a portable real-time reverse transcriptase-polymerase chain reaction assay for rapid detection of foot-and-mouth disease virus. J. Am. Vet. Med. Assoc. 220:16361642.

5. Deregt, D., S. A. Gilbert, S. Dudas, J. Pasick, S. Baxi, K. M. Burton, and M. K. Baxi. 2006. A multiplex DNA suspension microarray for simultaneous detection and differentiation of classical swine fever virus and other pestiviruses. J. Virol. Methods 136:17-23.

6. Dunbar, S. A. 2006. Applications of Luminex ${ }^{\circledR}$ xMAPTM technology for rapid, highthroughput multiplexed nucleic acid detection. Clin. Chim. Acta 363:71-82.

7. El-Kholy, A. A., S. R. Bolin, J. F. Ridpath, R. M. H. Arab, A. A. Abou-Zeid, H. M. Hammam, and K. B. Platt. 1998. Use of polymerase chain reaction to simultaneously detect and type bovine viral diarrhoea viruses isolated from clinical specimens. Rev. sci. Tech. Off. int. Epiz. 17:733-742.

8. Ferris, N. P., and M. Dawson. 1988. Routine application of enzyme-linked immunosorbent assay in comparison with complement fixation for the diagnosis of footand-mouth and swine vesicular diseases. Vet. Microbiol. 16:201-209.

9. Grubman, M. J., and B. Baxt. 2004. Foot-and-mouth disease. Clin. Microbiol. Rev. 17:465-493.

10. Han, J., D. C. Swan, S. J. Smith, S. H. Lum, S. E. Sefers, E. R. Unger, and Y.-W. Tang. 2006. Simultaneous amplification and identification of 25 human papillomavirus types with Templex technology. J. Clin. Microbiol. 44:4157-4162.

11. Hole, K., A. Clavijo, and L. A. Pineda. 2006. Detection and serotype-specific differentiation of vesicular stomatitis virus using a multiplex, real-time, reverse transcription-polymerase chain reaction assay. J. Vet. Diagn. Invest. 18:139-146.

12. James, A. D., and J. Rushton. 2002. The economics of foot and mouth disease. Rev. sci. Tech. Off. int. Epiz. 21:637-644.

13. Jiménez-Clavero, M. A., M. Agüero, E. S. Miguel, T. Mayoral, M. C. López, M. J. Ruano, E. Romero, F. Monaco, A. Polci, G. Savini, and C. Gómez-Tejedor. 2006. High throughput detection of bluetongue virus by a new real-time fluorogenic reverse transcription-polymerase chain reaction: Application on clinical samples from current Mediterranean outbreaks. J. Vet. Diagn. Invest. 18:7-17.

14. King, D. P., N. P. Ferris, A. E. Shaw, S. M. Reid, G. H. Hutchings, A. C. Giuffre, J. M. Robida, J. D. Callahan, W. M. Nelson, and T. R. Beckham. 2006. Detection of foot-and-mouth disease virus: comparative diagnostic sensitivity of two independent real- 
time reverse transcription-polymerase chain reaction assays. J. Vet. Diagn. Invest. 18:9397.

15. Kitching, P. R., P. V. Barnett, D. Paton, D. K. J. Mackay, and A. I. Donaldson. May 2006, posting date. Foot-and-mouth disease, Manual of Diagnostic Tests and Vaccines for Terrestrial Animals, 5th ed, vol. Part 2, Section 2.1, Chapter 2.1.1. Office International des Epizooties, Paris, France. http://www.oie.int/eng/normes/mmanual/A 00024.htm.

16. Kitching, R. P., and G. J. Hughes. 2002. Clinical variation in foot and mouth disease: sheep and goats. Rev. sci. Tech. Off. int. Epiz. 21:505-512.

17. Knowles, N. J., and A. R. Samuel. 2003. Molecular epidemiology of foot-and-mouth disease virus. Virus Res. 91:65-80.

18. Lee, W.-M., K. Grindle, T. Pappas, D. Marshall, M. Moser, E. Beaty, P. A. Shult, J. Prudent, and J. E. Gern. 2007. A high-throughput, sensitive and accurate multiplex PCR-microsphere flow cytometry system for large-scale comprehensive detection of respiratory viruses. J. Clin. Microbiol. doi:10.1128/JCM.02501-06:JCM.02501-06.

19. Létant, S. E., J. I. Ortiz, L. F. Bentley Tammero, J. M. Birch, R. W. Derlet, S. Cohen, D. Manning, and M. T. McBride. 2007. A multiplexed reverse transcriptase PCR assay for identification of viral respiratory pathogens at point-of-care. J. Clin. Microbiol. doi:10.1128/JCM.00880-07:JCM.00880-07.

20. Letellier, C., and P. Kerkhofs. 2003. Real-time PCR for simultaneous detection and genotyping of bovine viral diarrhea virus. J. Virol. Methods 114:21-27.

21. Li, H., M. A. McCormac, R. W. Estes, S. E. Sefers, R. K. Dare, J. D. Chappell, D. D. Erdman, P. F. Wright, and Y.-W. Tang. 2007. Simultaneous detection and highthroughput identification of a panel of RNA viruses causing respiratory tract Infections. J. Clin. Microbiol. 45:2105-2109.

22. Mahlum, C. E., S. Haugerud, J. L. Shivers, K. D. Rossow, S. M. Goyal, J. E. Collins, and K. S. Faaberg. 2002. Detection of bovine viral diarrhea virus by TaqMan ${ }^{\circledR}$ reverse transcription polymerase chain reaction. J. Vet. Diagn. Invest. 14:120-125.

23. Mahony, J., S. Chong, F. Merante, S. Yaghoubian, T. Sinha, C. Lisle, and R. Janeczko. 2007. Development of a Respiratory Virus Panel (RVP) Test for the Detection of Twenty Human Respiratory Viruses using Multiplex PCR and a Fluid Microbeadbased Assay. J. Clin. Microbiol. doi:10.1128/JCM.02436-06.

24. NCCLS. 1995. Assessment of the clinical accuracy of laboratory tests using receiver operating characteristic (ROC) plots. NCCLS, Wayne, PA.

25. NCCLS. 2002. User protocol for evaluation of qualtitative test performance; approved guideline. EP12-A. NCCLS, Wayne, PA.

26. Nitsche, A., M. Buttner, S. Wilhelm, G. Pauli, and H. Meyer. 2006. Real-time PCR detection of parapoxvirus DNA. Clin. Chem. 52:316-319.

27. Orrú, G., M. L. Ferrando, M. Meloni, M. Liciardi, G. Savini, and P. De Santis. 2006. Rapid detection and quantitation of Bluetongue virus (BTV) using a Molecular Beacon fluorescent probe assay. J. Virol. Methods 137:34-42.

28. Rasmussen, T. B., A. Uttenthal, and M. Agüero. 2006. Detection of three porcine vesicular viruses using multiplex real-time primer-probe energy transfer. J. Virol. Methods 134:176-182. 
29. Reid, S. M., N. P. Ferris, G. H. Hutchings, D. P. King, and S. Alexandersen. 2004. Evaluation of real-time reverse transcription polymerase chain reaction assays for the detection of swine vesicular disease virus. J. Virol. Methods 116:169-176.

30. Reid, S. M., N. P. Ferris, G. H. Hutchings, Z. D. Zhang, G. J. Belsham, and S. Alexandersen. 2002. Detection of all seven serotypes of foot-and-mouth disease virus by real-time, fluorogenic reverse transcription polymerase chain reaction assay. J. Virol. Methods 105:67-80.

31. Reid, S. M., D. P. King, A. E. Shaw, N. J. Knowles, G. H. Hutchings, E. J. Cooper, A. W. Smith, and N. P. Ferris. 2007. Development of a real-time reverse transcription polymerase chain reaction assay for detection of marine caliciviruses (genus Vesivirus). J. Virol. Methods 140:166-173.

32. Schmitt, M., I. G. Bravo, P. J. F. Snijders, L. Gissmann, M. Pawlita, and T. Waterboer. 2006. Bead-based multiplex genotyping of human papillomaviruses. J. Clin. Microbiol. 44:504-512.

33. Shaw, A. E., P. Monaghan, H. O. Alpar, S. Anthony, K. E. Darpel, C. A. Batten, A. Guercio, G. Alimena, M. Vitale, K. Bankowska, S. Carpenter, H. Jones, C. A. L. Oura, D. P. King, H. Elliott, P. S. Mellor, and P. P. C. Mertens. 2007. Development and initial evaluation of a real-time RT-PCR assay to detect bluetongue virus genome segment 1. J. Virol. Methods doi:10.1016/j.jviromet.2007.05.014.

34. Shaw, A. E., S. M. Reid, K. Ebert, G. H. Hutchings, N. P. Ferris, and D. P. King. 2007. Implementation of a one-step real-time RT-PCR protocol for diagnosis of foot-andmouth disease. J. Virol. Methods 143:81-85.

35. Shaw, A. E., S. M. Reid, D. P. King, G. H. Hutchings, and N. R. Ferris. 2004. Enhanced laboratory diagnosis of foot and mouth disease by real-time polymerase chain reaction. Rev. sci. Tech. Off. int. Epiz. 23:1003-1009.

36. Slezak, T., T. Kuczmarski, L. Ott, C. Torres, D. Medeiros, J. Smith, B. Truitt, N. Mulakken, M. Lam, E. Vitalis, A. Zemla, C. Zhou, and S. Gardner. 2003. Comparative genomics tools applied to bioterrorism defence. Brief Bioinform 4:133-49.

37. Traul, D. L., S. Elias, N. S. Taus, L. M. Herrmann, J. L. Oaks, and H. Li. 2005. A real-time PCR assay for measuring alcelaphine herpesvirus-1 DNA. J. Virol. Methods 129:186-190.

38. Vignali, D. A. A. 2000. Multiplexed particle-based flow cytometric assays. J. Immunol. Methods 243:243-255.

39. Young, N. J., C. J. Thomas, M. E. Collins, and J. Brownlie. 2006. Real-time RT-PCR detection of bovine viral diarrhoea virus in whole blood using an external RNA reference. J. Virol. Methods 138:218-222.

40. Zou, S., J. Han, L. Wen, Y. Liu, K. Cronin, S. H. Lum, L. Gao, J. Dong, Y. Zhang, Y. Guo, and Y. Shu. 2007. Human influenza A virus (H5N1) detection by a novel multiplex PCR typing method. J. Clin. Microbiol. 45:1889-1892. 


\section{Appendix}

\subsection{Area under the curve for ROC plots}

Table 5: Area under the curve for ROC plots for the independent results of the 5'UTR and 3D assays in rRT-PCR and mRT-PCR formats.

\begin{tabular}{lcccc}
\hline Serotype & \multicolumn{2}{c}{ rRT-PCR } & \multicolumn{2}{c}{ mRT-PCR } \\
& 5'UTR & 3D & 5'UTR & 3D \\
\hline A & 0.933 & 0.974 & 0.847 & 0.909 \\
Asia & 1.000 & 1.000 & 0.960 & 0.981 \\
C & 0.991 & 0.986 & 0.863 & 0.941 \\
O & 0.941 & 0.983 & 0.815 & 0.958 \\
SAT 1 & 0.920 & 0.997 & 0.548 & 1.000 \\
SAT 2 & 0.901 & 0.997 & 0.553 & 0.984 \\
SAT 3 & 0.971 & 0.997 & 0.536 & 1.000 \\
All & 0.942 & 0.985 & 0.773 & 0.955 \\
\hline
\end{tabular}




\subsection{Receiver Operating Characteristic (ROC) Plots}

3D rRT-PCR

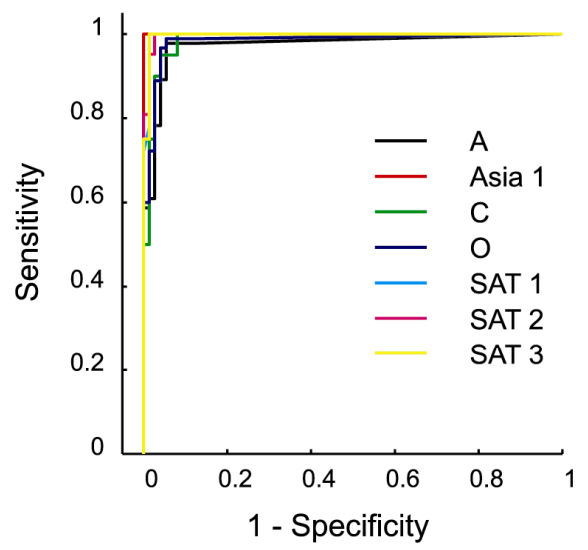

3D mRT-PCR

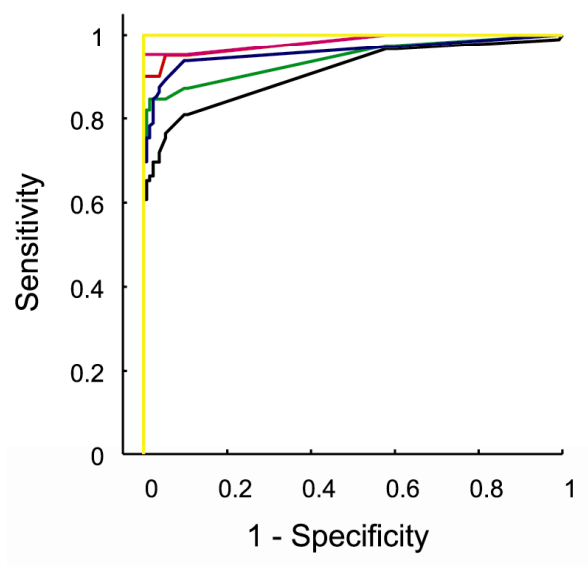

5'UTR rRT-PCR

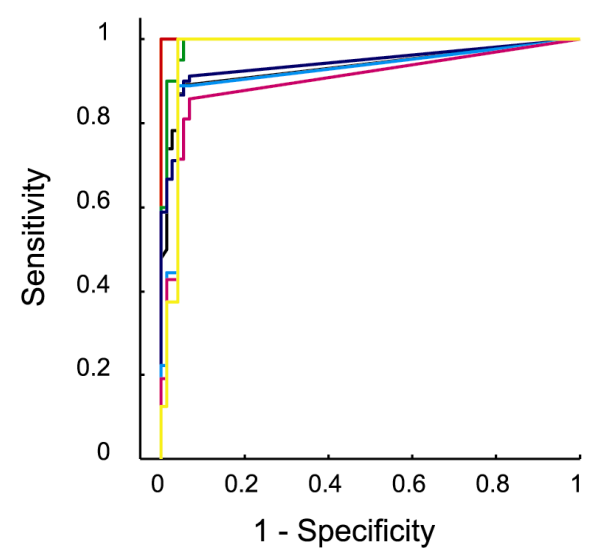

5'UTR mRT-PCR

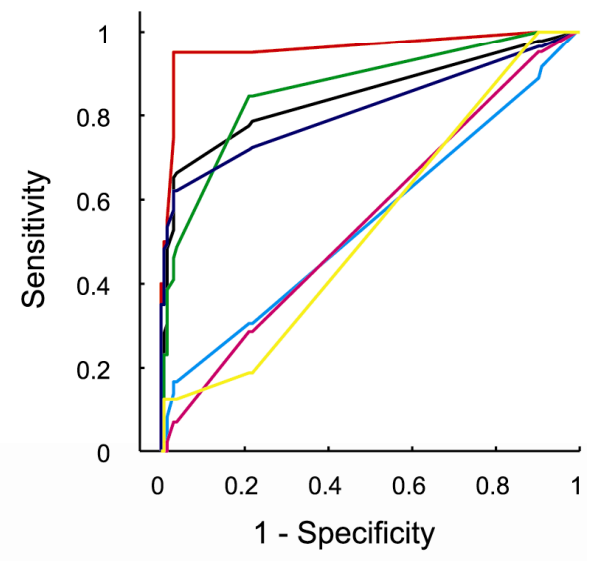

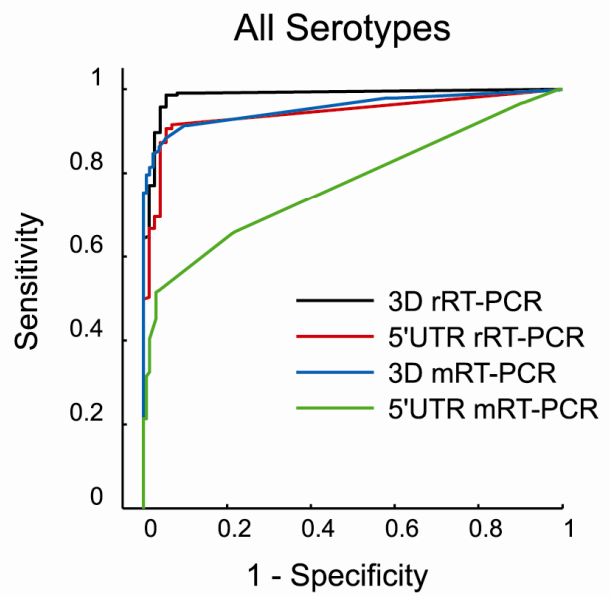

Figure 6: ROC plots for independent 3D and 5'UTR assays in rRT-PCR and mRT-PCR formats according to individual FMDV serotype and for all serotypes. VI with Ag-ELISA was the reference method used to assign samples as true negative of true positive. 
7.3. Response of 3D mRT-PCR assay vs 3D rRT-PCR assay according to FMDV serotype
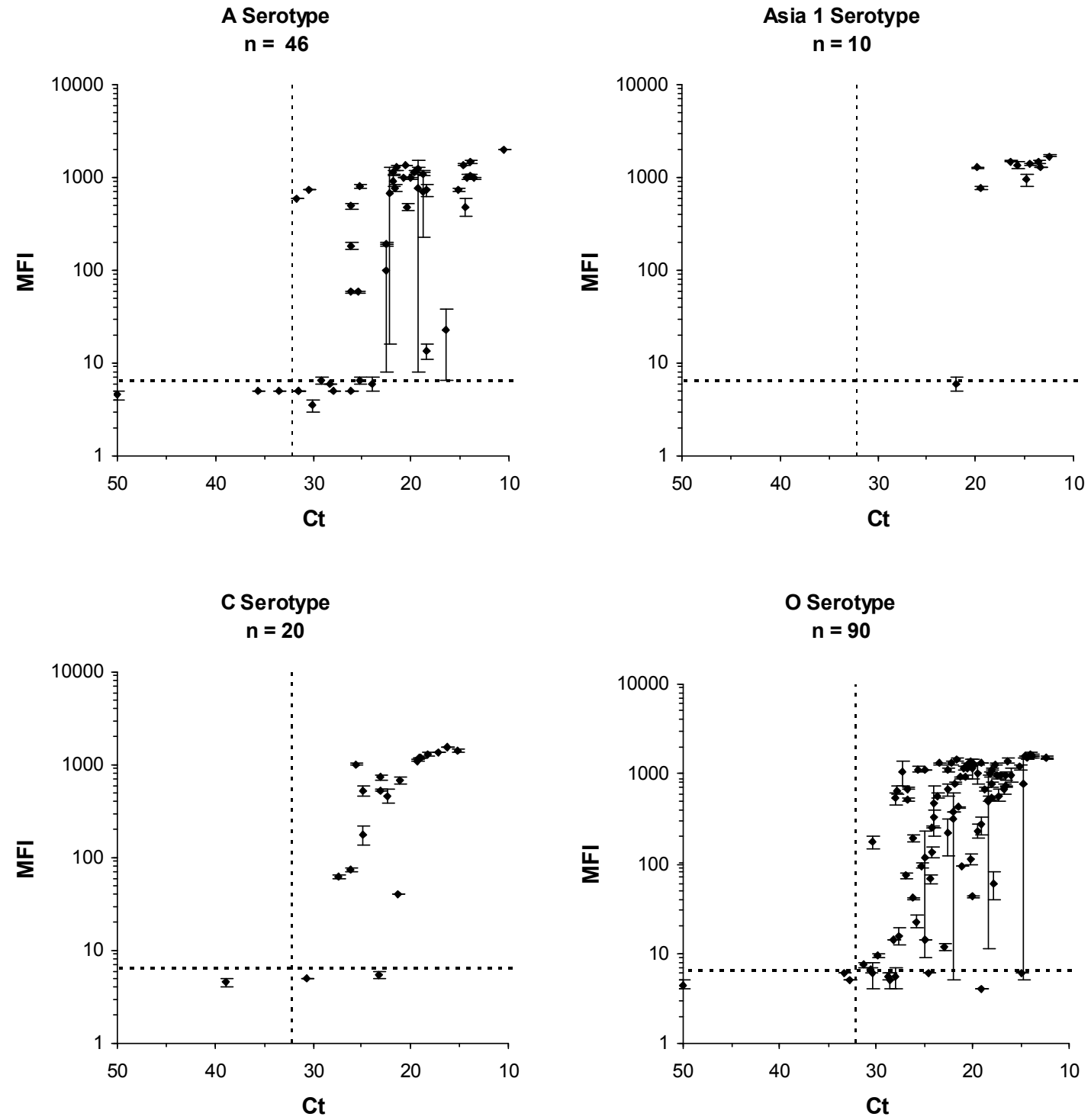

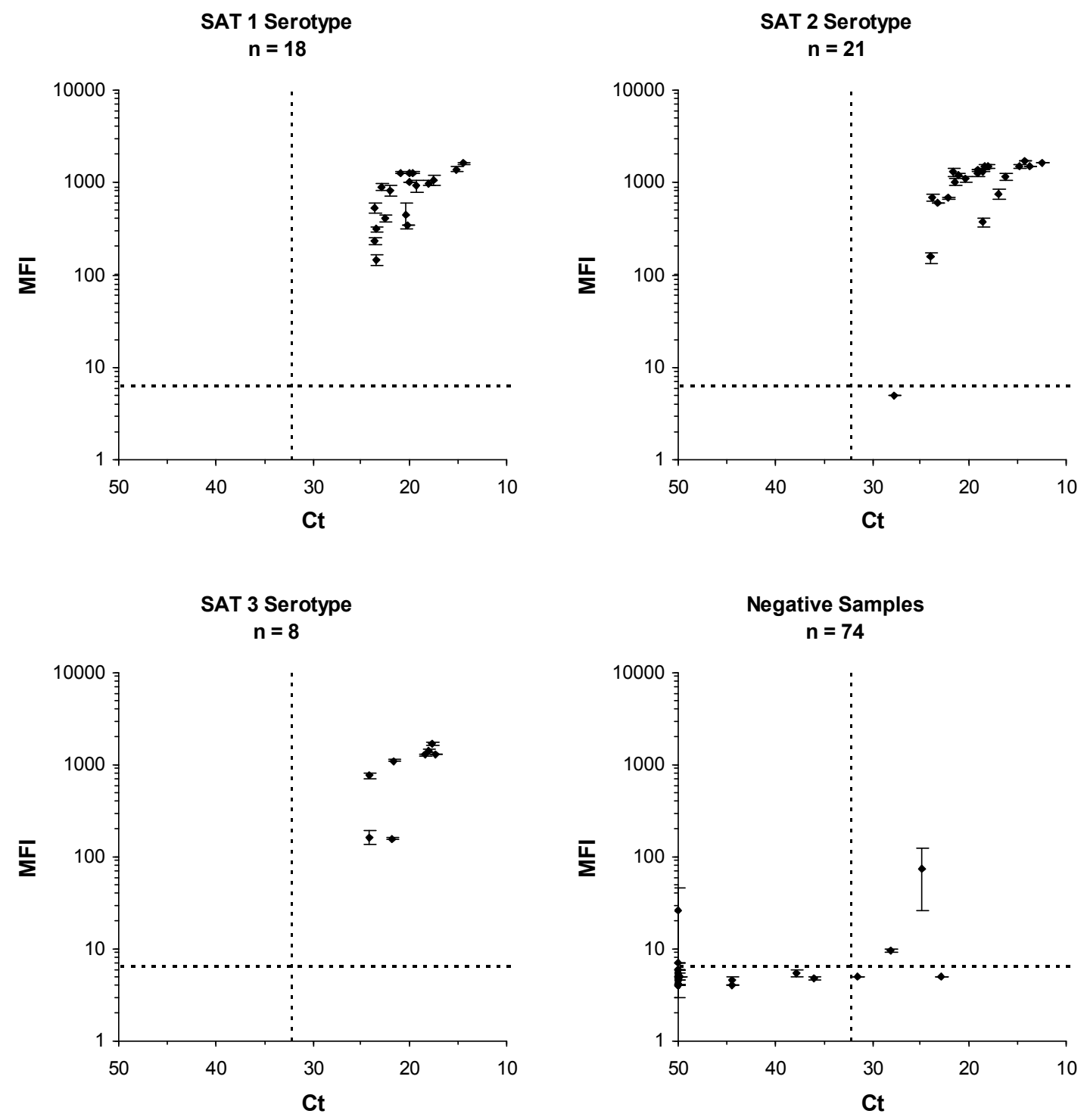

Figure 7. Comparison of the 3D assay response in mRT-PCR and singleplex rRT-PCR formats, where response is reported as median fluorescence intensity (MFI) and cycle threshold $(\mathrm{Ct})$, respectively. Results for 287 samples plotted according to FMDV serotype as determined by antigen-ELISA of the original suspension or cell culture supernatant. Cut-off values for rRT-PCR $(\mathrm{Ct} \leq 32)$ and $\mathrm{mRT}-\mathrm{PCR}(3 \mathrm{D} \mathrm{MFI} \geq 6.5)$ are indicated by the vertical and horizontal dashed lines, respectively. Error bars indicate $\pm 1 \sigma$ of the mean $(n=2)$ response from the signature in mRT-PCR format. For rRT-PCR each sample was analyzed in singlet $(n=1)$. 
7.4. Response of 5'UTR mRT-PCR assay vs 5'UTR rRT-PCR assay according to FMDV serotype
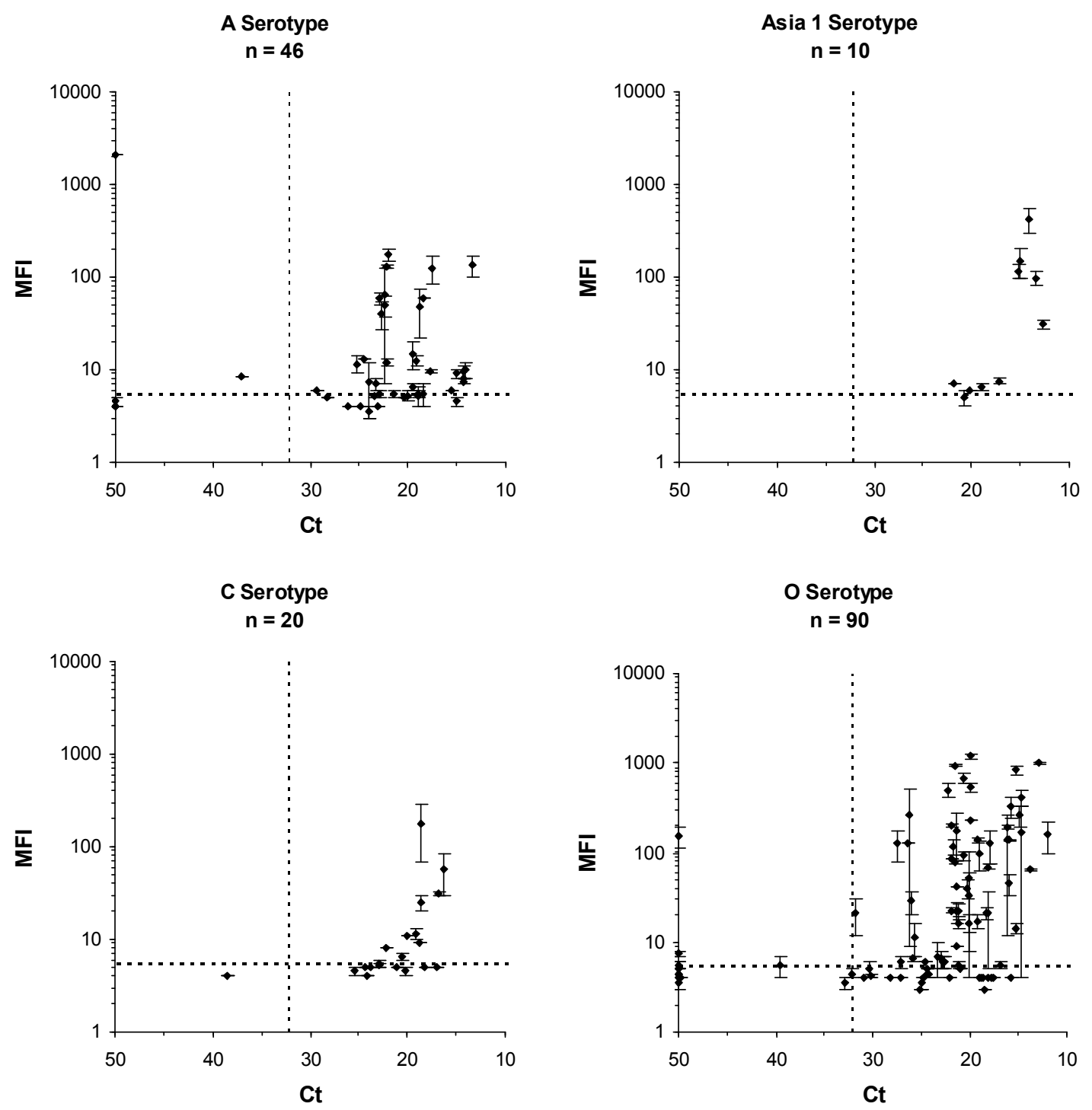

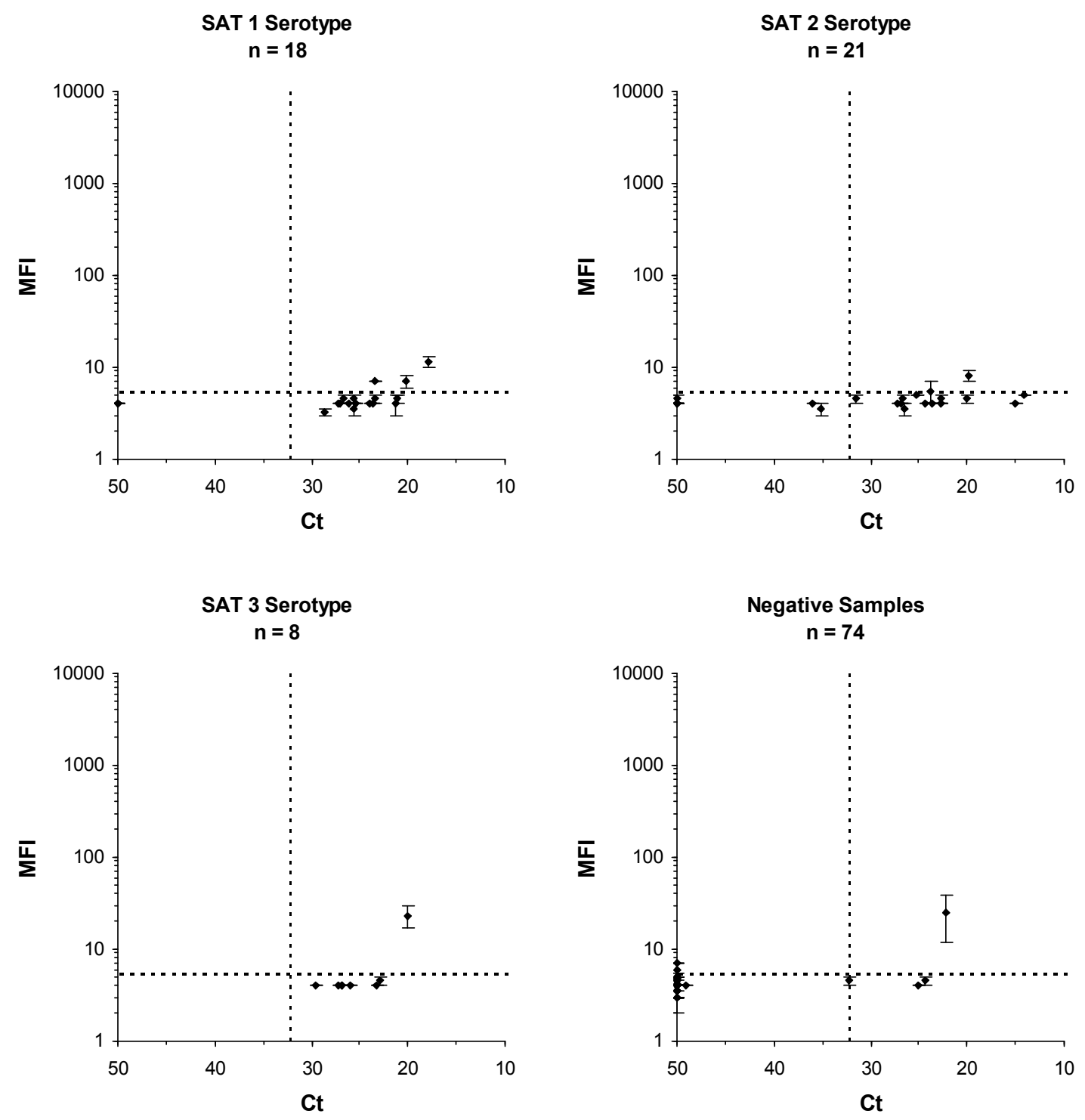

Figure 8. Comparison of the 5'UTR assay response in mRT-PCR and singleplex rRTPCR formats, where response is reported as median fluorescence intensity (MFI) and cycle threshold $(\mathrm{Ct})$, respectively. Results for 287 samples plotted according to FMDV serotype as determined by antigen-ELISA of the original suspension or cell culture supernatant. Cut-off values for rRT-PCR $(\mathrm{Ct} \leq 32)$ and mRT-PCR $\left(5^{\prime} \mathrm{UTR} \geq 5.5\right)$ are indicated by the vertical and horizontal dashed lines, respectively. Error bars indicate $\pm 1 \sigma$ of the mean $(n=2)$ response from the signature in mRT-PCR format. For rRT-PCR each sample was analyzed in singlet $(n=1)$. 


\subsection{Calculation of performance estimates}

The performance of the mRT-PCR was compared to singleplex rRT-PCR, using VI and AgELISA to define FMDV true positives and true negatives. Although VI and Ag-ELISA are established methods for the detection of FMDV, previous studies have demonstrated that rRTPCR has higher diagnostic sensitivity and can detect virus in additional samples, which for the purposes of this study would be classified as "true" negatives.

Performance estimates are calculated from test results run in parallel on all samples, as illustrated in Table 6.

Table 6: Theoretical $2 \times 2$ table.

\begin{tabular}{|r|c|c|c|}
\hline & \multicolumn{2}{|c|}{ True Diagnosis } & \\
\hline & Positive & Negative & Total \\
\hline Positive & $\mathrm{A}$ & $\mathrm{B}$ & $\mathrm{A}+\mathrm{B}$ \\
\hline Negative & $\mathrm{C}$ & $\mathrm{D}$ & $\mathrm{C}+\mathrm{D}$ \\
\hline Total & $\mathrm{A}+\mathrm{C}$ & $\mathrm{B}+\mathrm{D}$ & $\mathrm{N}$ \\
\hline
\end{tabular}

Sensitivity $=100 \%[\mathrm{~A} /(\mathrm{A}+\mathrm{C})]$

$95 \%$ Confidence Interval (C.I.) for sensitivity $=\left[100 \%\left(\mathrm{Q}_{1}-\mathrm{Q}_{2}\right) / \mathrm{Q}_{3}, 100 \%\left(\mathrm{Q}_{1}+\mathrm{Q}_{2}\right) / \mathrm{Q}_{3}\right]$

Where $\mathrm{Q}_{1}=2 \mathrm{~A}+3.84$

$\mathrm{Q}_{2}=1.96[3.84+4 \mathrm{AC} /(\mathrm{A}+\mathrm{C})]^{\wedge} 0.5$

$\mathrm{Q}_{3}=2(\mathrm{~A}+\mathrm{C})+7.68$

Estimated Specificity $=100 \%[\mathrm{D} /(\mathrm{B}+\mathrm{D})]$

$95 \%$ Confidence Interval (C.I.) for specificity $=\left[100 \%\left(\mathrm{Q}_{1}-\mathrm{Q}_{2}\right) / \mathrm{Q}_{3}, 100 \%\left(\mathrm{Q}_{1}+\mathrm{Q}_{2}\right) / \mathrm{Q}_{3}\right]$

Where $\mathrm{Q}_{1}=2 \mathrm{D}+3.84$

$$
\begin{aligned}
& \mathrm{Q}_{2}=1.96[3.84+4 \mathrm{BD} /(\mathrm{B}+\mathrm{D})]^{\wedge} 0.5 \\
& \mathrm{Q}_{3}=2(\mathrm{~B}+\mathrm{D})+7.68
\end{aligned}
$$

Disease prevalence $=100 \%[(\mathrm{~A}+\mathrm{C}) / \mathrm{N}]$

Positive Predictive Value $=100 \%[\mathrm{~A} /(\mathrm{A}+\mathrm{B})]$ 
Negative Predictive Value $=100 \%[\mathrm{D} /(\mathrm{C}+\mathrm{D})]$

Efficiency $=100 \%[(\mathrm{~A}+\mathrm{D}) / \mathrm{N}]$ 


\subsection{Diagnostic sensitivity and specificity estimates}

\subsection{1. $3 D$ rRT-PCR $2 \times 2$ Table}

Table 7: 3D rRT-PCR $2 \times 2$ table using VI with Ag-ELISA as the reference method.

\begin{tabular}{|r|c|c|c|}
\hline & \multicolumn{2}{|c|}{ True Diagnosis } & \\
\hline & Positive & Negative & Total \\
\hline Positive & 206 & 4 & 210 \\
\hline Negative & 7 & 70 & 77 \\
\hline Total & 213 & 74 & 287 \\
\hline
\end{tabular}

\subsubsection{5'UTR rRT-PCR $2 \times 2$ Table}

Table 8: 5'UTR rRT-PCR $2 \times 2$ table using VI with Ag-ELISA as the reference method.

\begin{tabular}{|r|c|c|c|}
\hline & \multicolumn{2}{|c|}{ True Diagnosis } & \\
\hline & Positive & Negative & Total \\
\hline Positive & 186 & 3 & 189 \\
\hline Negative & 27 & 71 & 98 \\
\hline Total & 213 & 74 & 287 \\
\hline
\end{tabular}

\subsubsection{Combined rRT-PCR $2 \times 2$ Table}

Table 9: Combined rRT-PCR $2 \times 2$ table using VI with Ag-ELISA as the reference method.

\begin{tabular}{|r|c|c|c|}
\hline & \multicolumn{2}{|c|}{ True Diagnosis } & \\
\hline & Positive & Negative & Total \\
\hline Positive & 209 & 5 & 214 \\
\hline Negative & 4 & 69 & 73 \\
\hline Total & 213 & 74 & 287 \\
\hline
\end{tabular}


7.6.4. $3 D m R T-P C R 2 \times 2$ Table

Table 10: 3D mRT-PCR $2 \times 2$ table using VI with Ag-ELISA as the reference method.

\begin{tabular}{|r|c|c|c|}
\hline & \multicolumn{2}{|c|}{ True Diagnosis } & \\
\hline & Positive & Negative & Total \\
\hline Positive & 192 & 5 & 197 \\
\hline Negative & 21 & 69 & 90 \\
\hline Total & 213 & 74 & 287 \\
\hline
\end{tabular}

7.6.5. 5'UTR $m R T$-PCR $2 \times 2$ Table

Table 11: 5'UTR mRT-PCR $2 \times 2$ table using VI with Ag-ELISA as the reference method.

\begin{tabular}{|r|c|c|c|}
\hline & \multicolumn{2}{|c|}{ True Diagnosis } & \\
\hline & Positive & Negative & Total \\
\hline Positive & 125 & 4 & 129 \\
\hline Negative & 88 & 70 & 158 \\
\hline Total & 213 & 74 & 287 \\
\hline
\end{tabular}

\subsubsection{Combined mRT-PCR $2 \times 2$ Table}

Table 12: Combined mRT-PCR $2 \times 2$ table using VI with Ag-ELISA as the reference method.

\begin{tabular}{|r|c|c|c|}
\hline & \multicolumn{2}{|c|}{ True Diagnosis } & \\
\hline & Positive & Negative & Total \\
\hline Positive & 200 & 6 & 206 \\
\hline Negative & 13 & 68 & 81 \\
\hline Total & 213 & 74 & 287 \\
\hline
\end{tabular}




\subsection{Detection channel cross-talk}

Table 13: Correlation coefficients between the mRT-PCR FMDV 3D or 5'UTR detection channels with the other fifteen detection channels.

\begin{tabular}{|l|c|c|c|c|}
\hline \multirow{2}{*}{ Assay } & \multicolumn{4}{|c|}{ Correlation Coefficient } \\
\cline { 2 - 5 } & \multicolumn{2}{|c|}{ All samples } & \multicolumn{2}{c|}{ FMDV + samples } \\
\cline { 2 - 5 } & FMDV 3D & FMDV 5'UTR & FMDV 3D & FMDV 5'UTR \\
\hline BHV-1 & -0.107 & -0.003 & -0.195 & -0.017 \\
\hline PPOX-1 & 0.167 & 0.055 & 0.123 & 0.037 \\
\hline PPOX-2 & -0.075 & -0.021 & 0.029 & 0.009 \\
\hline PPOX-3 & -0.078 & -0.092 & -0.168 & -0.156 \\
\hline BVDV & -0.087 & -0.027 & -0.083 & 0.114 \\
\hline BTV-1 & 0.067 & 0.024 & 0.074 & 0.023 \\
\hline BTV-2 & 0.009 & 0.057 & 0.046 & 0.080 \\
\hline SVD-1 & -0.054 & -0.034 & -0.102 & -0.048 \\
\hline SVD-2 & -0.027 & -0.140 & 0.011 & -0.141 \\
\hline SVD-3 & -0.001 & -0.108 & 0.067 & -0.102 \\
\hline VESV-1 & -0.069 & -0.053 & -0.089 & -0.059 \\
\hline VESV-2 & 0.085 & -0.069 & 0.209 & -0.053 \\
\hline VESV-3 & 0.005 & -0.075 & 0.070 & -0.077 \\
\hline VESV-4 & 0.047 & -0.141 & 0.145 & -0.135 \\
\hline
\end{tabular}

"All samples" contains 550 measurements from 213 FMD-positive samples and 74 FMDnegative samples. "FMD+ samples" contains 417 measurements from 213 FMD-positive samples. In "all samples", the correlation coefficients between FMDV 3D and FMDV 5'UTR channels with all other detection channels did not exceed 0.167 and 0.057 , respectively. In "FMD+ samples", the correlation coefficients between FMDV 3D and FMDV 5'UTR channels with all other detection channels did not exceed 0.209 and 0.114 , respectively. 


\subsection{Raw data for 287 samples used for the diagnostic evaluation of the mRT-PCR assay.}

Table 14: Raw data for 287 samples used for the diagnostic evaluation of the mRT-PCR assay. Table key: $+=$ positive, $-=$ negative. mRT-PCR results key: $++=$ positive for both duplicate measurements, -- = negative for both duplicate measurements, $+/-=$ positive in one duplicate and negative in other duplicate, $+=$ positive in one duplicate and the other duplicate not performed, - = negative in one duplicate and the other duplicate not performed

\begin{tabular}{|c|c|c|c|c|c|c|c|}
\hline Isolate & Serotype & $\begin{array}{c}\text { 3D } \\
\text { rRT-PCR }\end{array}$ & $\begin{array}{c}\text { 5'UTR } \\
\text { rRT-PCR }\end{array}$ & $\begin{array}{c}\text { Combined } \\
\text { rRT-PCR }\end{array}$ & $\begin{array}{c}\text { 3D } \\
\text { mRT-PCR }\end{array}$ & $\begin{array}{c}\text { 5'UTR } \\
\text { mRT-PCR }\end{array}$ & $\begin{array}{l}\text { Combined } \\
\text { mRT-PCR }\end{array}$ \\
\hline ARG 1/2001 & FMD A & + & + & + & ++ & ++ & + \\
\hline BHU 35/2003 & FMD A & + & - & + & + & + & + \\
\hline BHU 35/2003 & FMD A & + & + & + & -- & +- & + \\
\hline BHU 41/2002 & FMD A & + & + & + & +- & +- & + \\
\hline BHU 6/2003 & FMD A & + & + & + & + & + & + \\
\hline BHU 6/2003 & FMD A & + & + & + & ++ & ++ & + \\
\hline ERI $3 / 98$ & FMD A & + & + & + & ++ & -- & + \\
\hline IRN 10/2003 & FMD A & + & + & + & ++ & ++ & + \\
\hline IRN 10/2005 & FMD A & + & + & + & ++ & ++ & + \\
\hline IRN 14/2005 & FMD A & + & + & + & ++ & +- & + \\
\hline IRN 16/2005 & FMD A & + & + & + & ++ & ++ & + \\
\hline IRN 17/2005 & FMD A & + & + & + & ++ & -- & + \\
\hline IRN 21/2000 & FMD A & + & + & + & ++ & -- & + \\
\hline IRN 26/2003 & FMD A & + & + & + & ++ & ++ & + \\
\hline IRN 4/2000 & FMD A & + & + & + & ++ & ++ & + \\
\hline IRN 41/2003 & FMD A & + & + & + & ++ & ++ & + \\
\hline IRN 5/2003 & FMD A & + & + & + & ++ & -- & + \\
\hline IRN 6/2002 & FMD A & + & - & + & + & + & + \\
\hline IRN 7/2000 & FMD A & + & - & + & ++ & -- & + \\
\hline IRN 7/2004 & FMD A & + & + & + & ++ & +- & + \\
\hline IRQ 59/2002 & FMD A & + & + & + & ++ & ++ & + \\
\hline MAI 4/2004 & FMD A & + & - & + & -- & -- & - \\
\hline MAY 4/2003 & FMD A & + & + & + & ++ & ++ & + \\
\hline NIG 12/1974 & FMD A & - & - & - & -- & -- & - \\
\hline PAK 20/2006 & FMD A & + & + & + & ++ & ++ & + \\
\hline PAK 21/2006 & FMD A & + & + & + & ++ & ++ & + \\
\hline PAK 22/2006 & FMD A & + & + & + & ++ & -- & + \\
\hline PAK 23/2006 & FMD A & + & + & + & ++ & ++ & + \\
\hline PAK 25/2006 & FMD A & + & + & + & ++ & ++ & + \\
\hline PAK 28/2002 & FMD A & + & + & + & ++ & +- & + \\
\hline PAK 77/2003 & FMD A & + & + & + & ++ & +- & + \\
\hline SYR 5/2002 & FMD A & + & + & + & ++ & -- & + \\
\hline SYR 5/2002 & FMD A & + & + & + & ++ & ++ & + \\
\hline SYR 9/2002 & FMD A & - & + & + & -- & ++ & + \\
\hline TAI 3/2001 & FMD A & + & + & + & +- & ++ & + \\
\hline TAI 4/2003 & FMD A & + & + & + & ++ & ++ & + \\
\hline TAI 4/2003 & FMD A & + & + & + & ++ & ++ & + \\
\hline TOG 9/2005 & FMD A & + & - & + & ++ & -- & + \\
\hline TUR 1/2000 & FMD A & + & + & + & ++ & ++ & + \\
\hline
\end{tabular}




\begin{tabular}{|c|c|c|c|c|c|c|c|}
\hline Isolate & Serotype & $\begin{array}{c}\text { 3D } \\
\text { rRT-PCR }\end{array}$ & $\begin{array}{c}\text { 5'UTR } \\
\text { rRT-PCR }\end{array}$ & $\begin{array}{l}\text { Combined } \\
\text { rRT-PCR }\end{array}$ & $\begin{array}{c}\text { 3D } \\
\text { mRT-PCR }\end{array}$ & $\begin{array}{c}\text { 5'UTR } \\
\text { mRT-PCR }\end{array}$ & $\begin{array}{l}\text { Combined } \\
\text { mRT-PCR }\end{array}$ \\
\hline TUR 1/2000 & FMD A & + & + & + & ++ & ++ & + \\
\hline TUR 1/2002 & FMD A & + & + & + & +- & +- & + \\
\hline TUR 14/2002 & FMD A & + & + & + & -- & ++ & + \\
\hline TUR 15/2002 & FMD A & + & + & + & - - & ++ & + \\
\hline TUR 16/2002 & FMD A & + & + & + & - & -- & - \\
\hline TUR 4/2000 & FMD A & - & + & + & -- & ++ & + \\
\hline TUR 4/2003 & FMD A & + & + & + & -- & +- & + \\
\hline AFG 3/2001 & FMD Asia 1 & + & + & + & ++ & ++ & + \\
\hline BHU 27/2002 & FMD Asia 1 & + & + & + & ++ & ++ & + \\
\hline GRE 2/2000 & FMD Asia 1 & + & + & + & ++ & ++ & + \\
\hline HKN 8/2005 & FMD Asia 1 & + & + & + & ++ & ++ & + \\
\hline IND 5/89 & FMD Asia 1 & + & + & + & ++ & ++ & + \\
\hline IRN 30/2004 & FMD Asia 1 & + & + & + & ++ & ++ & + \\
\hline PAK 1/2004 & FMD Asia 1 & + & + & + & ++ & ++ & + \\
\hline PAK 48/2003 & FMD Asia 1 & + & + & + & +- & +- & + \\
\hline TAI 1/98 & FMD Asia 1 & + & + & + & ++ & ++ & + \\
\hline TUR 3/2000 & FMD Asia 1 & + & + & + & ++ & ++ & + \\
\hline ANG 2/73 & FMD C & + & + & + & ++ & ++ & + \\
\hline AUR 4/73 & FMD C & + & + & + & ++ & -- & + \\
\hline BEL 1/69 & FMD C & + & + & + & ++ & ++ & + \\
\hline BEL 1/72 & FMD C & + & + & + & ++ & -- & + \\
\hline C ARG/84 & FMD C & + & + & + & + & + & + \\
\hline FRA $3 / 74$ & FMD C & + & + & + & ++ & -- & + \\
\hline HUN 2/72 & FMD C & + & + & + & ++ & -- & + \\
\hline IND 16/81 & FMD C & + & + & + & ++ & ++ & + \\
\hline ISO 3 bovine EPI & FMD C & + & + & + & ++ & -- & + \\
\hline ISO 5 NV 19 & FMD C & + & + & + & ++ & -- & + \\
\hline ITL 4/89 & FMD C & + & + & + & ++ & -- & + \\
\hline KUW 9/82 & FMD C & + & + & + & ++ & ++ & + \\
\hline PHI 2/89 & FMD C & - & - & - & -- & -- & - \\
\hline $\mathrm{PHI} 3 / 94$ & FMD C & + & + & + & -- & ++ & + \\
\hline PHI 3/94 & FMD C & + & + & + & -- & -- & - \\
\hline SAU 14/84 & FMD C & + & + & + & ++ & ++ & + \\
\hline SRL 4/78 & FMD C & + & + & + & ++ & ++ & + \\
\hline UKG 70/74 & FMD C & + & + & + & ++ & +- & + \\
\hline UKG 70/74 & FMD C & + & + & + & ++ & +- & + \\
\hline USS 4/74 & FMD C & + & + & + & ++ & ++ & + \\
\hline BHU 22/2003 & FMD O & + & - & + & ++ & -- & + \\
\hline BHU 48/2003 & FMD O & + & + & + & ++ & ++ & + \\
\hline BHU 7/2002 & FMD O & + & + & + & +- & +- & + \\
\hline BUN 6/2003 & FMD O & + & + & + & ++ & -- & + \\
\hline CAM 13/99 & FMD O & + & + & + & ++ & ++ & + \\
\hline CAR 86/2005 & FMD O & + & - & + & ++ & -- & + \\
\hline HKN 11/2004 & FMD O & + & + & + & ++ & -- & + \\
\hline HKN 12/2005 & FMD O & + & + & + & ++ & -- & + \\
\hline HKN 19/2001 & FMD O & + & - & + & -- & -- & - \\
\hline HKN 3/2003 & FMD O & + & + & + & +- & -- & + \\
\hline HKN 3/2004 & FMD O & + & + & + & ++ & -- & + \\
\hline
\end{tabular}




\begin{tabular}{|c|c|c|c|c|c|c|c|}
\hline Isolate & Serotype & $\begin{array}{c}\text { 3D } \\
\text { rRT-PCR }\end{array}$ & $\begin{array}{c}\text { 5'UTR } \\
\text { rRT-PCR }\end{array}$ & $\begin{array}{l}\text { Combined } \\
\text { rRT-PCR }\end{array}$ & $\begin{array}{c}\text { 3D } \\
\text { mRT-PCR }\end{array}$ & $\begin{array}{c}\text { 5'UTR } \\
\text { mRT-PCR }\end{array}$ & $\begin{array}{l}\text { Combined } \\
\text { mRT-PCR }\end{array}$ \\
\hline IRN 2/2003 & FMD O & + & - & + & ++ & -- & + \\
\hline IRN 27/2003 & FMD O & + & + & + & ++ & ++ & + \\
\hline IRN 8/2001 & FMD O & + & + & + & -- & -- & - \\
\hline ISA $1 / 74$ & FMD O & + & + & + & ++ & ++ & + \\
\hline ISA $9 / 74$ & FMD O & + & + & + & ++ & ++ & + \\
\hline JOR 1/99 & FMD O & + & + & + & +- & +- & + \\
\hline KEN 5/2002 & FMD O & + & + & + & ++ & -- & + \\
\hline KEN 5/2002 & FMD O & + & + & + & ++ & ++ & + \\
\hline KEN 6/2002 & FMD O & + & + & + & ++ & -- & + \\
\hline LAO 1/2003 & FMD O & + & + & + & ++ & ++ & + \\
\hline LAO 17/2003 & FMD O & + & + & + & ++ & ++ & + \\
\hline LAO 2/2003 & FMD O & + & + & + & ++ & +- & + \\
\hline LAO 21/2003 & FMD O & + & + & + & + & + & + \\
\hline LAO 26/2003 & FMD O & + & + & + & ++ & ++ & + \\
\hline LAO 29/2003 & FMD O & - & + & + & -- & -- & - \\
\hline LAO 31/2003 & FMD O & + & + & + & ++ & +- & + \\
\hline LAO 34/2003 & FMD O & + & + & + & ++ & ++ & + \\
\hline LAO 7/2003 & FMD O & + & + & + & ++ & ++ & + \\
\hline LAO 8/98 & FMD O & + & + & + & ++ & +- & + \\
\hline LEB 5/99 & FMD O & + & - & + & ++ & ++ & + \\
\hline MAI 2/2005 & FMD O & + & + & + & ++ & +- & + \\
\hline MAU 15/2001 & FMD O & + & - & + & ++ & ++ & + \\
\hline MAU 19/2000 & FMD O & + & - & + & +- & +- & + \\
\hline MAY 1/2001 & FMD O & + & + & + & ++ & ++ & + \\
\hline MAY 1/2002 & FMD O & + & + & + & ++ & ++ & + \\
\hline MAY 2/2004 & FMD O & + & + & + & ++ & ++ & + \\
\hline MAY 5/2002 & FMD O & + & + & + & + & + & + \\
\hline MAY 6/2003 & FMD O & + & + & + & ++ & ++ & + \\
\hline MYA 1/2001 & FMD O & + & + & + & ++ & ++ & + \\
\hline MYA 4/2002 & FMD O & + & + & + & ++ & ++ & + \\
\hline NEP $12 / 2000$ & FMD O & + & + & + & ++ & ++ & + \\
\hline NEP 13/2000 & FMD O & + & + & + & ++ & ++ & + \\
\hline NEP 4/2003 & FMD O & + & + & + & ++ & -- & + \\
\hline NEP 6/2003 & FMD O & + & + & + & ++ & ++ & + \\
\hline $\begin{array}{c}\text { NGR } 11 / 2001 \\
\text { O1 BFS } 1860 \text { Pig }\end{array}$ & FMD O & + & + & + & ++ & ++ & + \\
\hline SE24 & FMD O & + & + & + & ++ & ++ & + \\
\hline O1 Manisa & FMD O & + & - & + & -- & +- & + \\
\hline O1 Manisa +ve & FMD O & + & + & + & - & - & - \\
\hline O1 Manisa +ve & FMD O & - & - & - & -- & -- & - \\
\hline $\begin{array}{c}\text { O1 Manisa 3/5/2006 } \\
\text { O1 Manisa }\end{array}$ & FMD O & + & + & + & - & - & - \\
\hline $30 / 10 / 2006$ & FMD O & + & + & + & ++ & -- & + \\
\hline OMN 2/2001 & FMD O & + & + & + & ++ & ++ & + \\
\hline PAK 1/2003 & FMD O & + & + & + & ++ & -- & + \\
\hline PAK 28/2006 & FMD O & + & + & + & ++ & - - & + \\
\hline PAK 29/2006 & FMD O & + & + & + & ++ & -- & + \\
\hline PAK 33/2006 & FMD O & + & + & + & ++ & -- & + \\
\hline PAK 34/2006 & FMD O & + & + & + & ++ & -- & + \\
\hline
\end{tabular}




\begin{tabular}{|c|c|c|c|c|c|c|c|}
\hline Isolate & Serotype & $\begin{array}{c}\text { 3D } \\
\text { rRT-PCR }\end{array}$ & $\begin{array}{c}\text { 5'UTR } \\
\text { rRT-PCR }\end{array}$ & $\begin{array}{l}\text { Combined } \\
\text { rRT-PCR }\end{array}$ & $\begin{array}{c}\text { 3D } \\
\text { mRT-PCR }\end{array}$ & $\begin{array}{c}\text { 5'UTR } \\
\text { mRT-PCR }\end{array}$ & $\begin{array}{l}\text { Combined } \\
\text { mRT-PCR }\end{array}$ \\
\hline PAK 35/2006 & FMD O & + & + & + & ++ & +- & + \\
\hline PAK 36/2006 & FMD O & + & + & + & ++ & -- & + \\
\hline PAK 37/2006 & FMD O & + & + & + & ++ & +- & + \\
\hline PHI 1/2005 & FMD O & + & + & + & ++ & ++ & + \\
\hline $\mathrm{PHI} 2 / 2005$ & FMD O & + & + & + & ++ & ++ & + \\
\hline PHI 20/2003 & FMD O & + & + & + & ++ & ++ & + \\
\hline PHI 3/2005 & FMD O & + & + & + & ++ & ++ & + \\
\hline PHI 3/2005 & FMD O & + & + & + & ++ & ++ & + \\
\hline PHI 8/2001 & FMD O & + & + & + & ++ & ++ & + \\
\hline SAU $1 / 2002$ & FMD O & + & + & + & ++ & ++ & + \\
\hline SRL 1/2000 & FMD O & + & + & + & ++ & ++ & + \\
\hline SYR 1/2002 & FMD O & + & + & + & ++ & -- & + \\
\hline TAN 1/99 & FMD O & + & + & + & ++ & +- & + \\
\hline TAW 84/94 & FMD O & + & + & + & ++ & ++ & + \\
\hline TAW 9/1997 & FMD O & + & + & + & + & + & + \\
\hline TOG 1/2004 & FMD O & + & + & + & ++ & +- & + \\
\hline TUR 1/2003 & FMD O & + & + & + & ++ & + & + \\
\hline TUR 3/2003 & FMD O & + & + & + & ++ & ++ & + \\
\hline TUR 5/2002 & FMD O & + & + & + & ++ & ++ & + \\
\hline UAE 2/2003 & FMD O & + & + & + & ++ & +- & + \\
\hline UGA 4/2004 & FMD O & + & - & + & ++ & -- & + \\
\hline UKG 13,305/2001 & FMD O & + & + & + & ++ & ++ & + \\
\hline UKG 14004/2001 & FMD O & + & - & + & ++ & +- & + \\
\hline UKG 312/2001 & FMD O & + & + & + & ++ & ++ & + \\
\hline UKG 9804/2001 & FMD O & + & + & + & ++ & ++ & + \\
\hline URU 1/2000 & FMD O & + & + & + & +- & ++ & + \\
\hline URU 1/2000 & FMD O & + & + & + & ++ & ++ & + \\
\hline VIT 13/2002 & FMD O & + & + & + & ++ & ++ & + \\
\hline VIT 19/99 & FMD O & + & + & + & ++ & ++ & + \\
\hline VIT 2/2002 & FMD O & + & + & + & ++ & ++ & + \\
\hline VIT 6/2002 & FMD O & + & + & + & ++ & ++ & + \\
\hline YEM 1/2001 & FMD O & - & - & - & -- & -- & - \\
\hline ВОТ 2/68 & FMD SAT 1 & + & + & + & ++ & -- & + \\
\hline ВОТ 2/68 & FMD SAT 1 & + & + & + & ++ & ++ & + \\
\hline GHA 3/69 & FMD SAT 1 & + & - & + & ++ & -- & + \\
\hline GHA 3/69 & FMD SAT 1 & + & - & + & ++ & -- & + \\
\hline KEN 1/2005 & FMD SAT 1 & + & + & + & ++ & ++ & + \\
\hline KEN 1/2005 & FMD SAT 1 & + & + & + & ++ & -- & + \\
\hline MOZ 11/78 & FMD SAT 1 & + & + & + & ++ & - - & + \\
\hline RHO 1/80 & FMD SAT 1 & + & + & + & ++ & -- & + \\
\hline RHO 5/66 & FMD SAT 1 & + & + & + & ++ & ++ & + \\
\hline RV 11/37 15/9/37 & FMD SAT 1 & + & + & + & ++ & -- & + \\
\hline SAR $17 / 80$ & FMD SAT 1 & + & + & + & ++ & -- & + \\
\hline SAR 6/74 & FMD SAT 1 & + & + & + & ++ & -- & + \\
\hline SWA $1 / 80$ & FMD SAT 1 & + & + & + & ++ & -- & + \\
\hline TAN 28/99 & FMD SAT 1 & + & + & + & ++ & -- & + \\
\hline TAN 36/99 & FMD SAT 1 & + & + & + & ++ & -- & + \\
\hline UGA 3/99 & FMD SAT 1 & + & + & + & ++ & -- & + \\
\hline
\end{tabular}




\begin{tabular}{|c|c|c|c|c|c|c|c|}
\hline Isolate & Serotype & $\begin{array}{c}\text { 3D } \\
\text { rRT-PCR }\end{array}$ & $\begin{array}{c}\text { 5'UTR } \\
\text { rRT-PCR }\end{array}$ & $\begin{array}{c}\text { Combined } \\
\text { rRT-PCR }\end{array}$ & $\begin{array}{c}\text { 3D } \\
\text { mRT-PCR }\end{array}$ & $\begin{array}{c}\text { 5'UTR } \\
\text { mRT-PCR }\end{array}$ & $\begin{array}{l}\text { Combined } \\
\text { mRT-PCR }\end{array}$ \\
\hline ZAM 28/2004 & FMD SAT 1 & + & + & + & ++ & -- & + \\
\hline ZIM 3/85 & FMD SAT 1 & + & + & + & ++ & - & + \\
\hline ВОТ 1/2005 & FMD SAT 2 & + & + & + & ++ & - & + \\
\hline ВОТ 13/2002 & FMD SAT 2 & + & + & + & ++ & - & + \\
\hline ВОТ 13/2002 & FMD SAT 2 & + & + & + & ++ & - - & + \\
\hline CAR 117/2005 & FMD SAT 2 & + & - & + & ++ & - & + \\
\hline CAR 5/2000 & FMD SAT 2 & + & - & + & ++ & -- & + \\
\hline ERI 4/98 & FMD SAT 2 & + & + & + & ++ & -- & + \\
\hline IVC 8/75 & FMD SAT 2 & + & + & + & ++ & -- & + \\
\hline KEN 2/2002 & FMD SAT 2 & + & + & + & ++ & -- & + \\
\hline KEN 7/2004 & FMD SAT 2 & + & + & + & ++ & ++ & + \\
\hline KEN 7/2004 & FMD SAT 2 & + & + & + & ++ & -- & + \\
\hline LIB 1/2003 & FMD SAT 2 & + & + & + & ++ & -- & + \\
\hline MAI 7/91 & FMD SAT 2 & + & + & + & ++ & - & + \\
\hline MAL 4/75 & FMD SAT 2 & + & + & + & ++ & - & + \\
\hline MOZ 20/78 & FMD SAT 2 & + & + & + & ++ & - & + \\
\hline RHO 3/80 & FMD SAT 2 & + & + & + & ++ & +- & + \\
\hline SAU $13 / 2000$ & FMD SAT 2 & + & - & + & ++ & -- & + \\
\hline SAU 4/2000 & FMD SAT 2 & + & - & + & ++ & -- & + \\
\hline SAU 4/20000 & FMD SAT 2 & + & - & + & ++ & -- & + \\
\hline UGA 20/98 & FMD SAT 2 & + & + & + & ++ & - & + \\
\hline ZIM 11/91 & FMD SAT 2 & + & - & + & -- & - & - \\
\hline ZIM 2/97 & FMD SAT 2 & + & + & + & ++ & -- & + \\
\hline BEC 2/65 & FMD SAT 3 & + & + & + & ++ & ++ & + \\
\hline MAL 3/76 & FMD SAT 3 & + & + & + & ++ & -- & + \\
\hline RHO 1/74 & FMD SAT 3 & + & + & + & ++ & - & + \\
\hline RHO 2/74 & FMD SAT 3 & + & + & + & ++ & -- & + \\
\hline SAR $4 / 80$ & FMD SAT 3 & + & + & + & ++ & -- & + \\
\hline ZIM 1/84 & FMD SAT 3 & + & + & + & ++ & -- & + \\
\hline ZIM 1/84 & FMD SAT 3 & + & + & + & ++ & -- & + \\
\hline ZIM 6/91 & FMD SAT 3 & + & + & + & ++ & - - & + \\
\hline BEN 1/2005 & Negative & - & - & - & -- & -- & - \\
\hline BEN 10/2005 & Negative & - & - & - & -- & - - & - \\
\hline BEN 11/2005 & Negative & - & - & - & -- & - & - \\
\hline BEN 12/2005 & Negative & - & - & - & -- & - & - \\
\hline BEN 13/2005 & Negative & - & - & - & -- & - & - \\
\hline BEN 14/2005 & Negative & - & - & - & - - & -- & - \\
\hline BEN 15/2005 & Negative & - & - & - & -- & - & - \\
\hline BEN 16/2005 & Negative & - & - & - & - - & -- & - \\
\hline BEN 2/2005 & Negative & - & - & - & - & - & - \\
\hline BEN 32005 & Negative & - & - & - & - & - & - \\
\hline BEN 4/2005 & Negative & - & - & - & -- & -- & - \\
\hline BEN 5/2005 & Negative & - & - & - & -- & -- & - \\
\hline BEN 6/2005 & Negative & - & - & - & - & - - & - \\
\hline BEN 7/2005 & Negative & - & - & - & - & - & - \\
\hline BEN 8/2005 & Negative & - & - & - & - - & -- & - \\
\hline BEN 9/2005 & Negative & - & - & - & -- & -- & - \\
\hline IRL 5/2006 & Negative & - & - & - & - & - & - \\
\hline
\end{tabular}




\begin{tabular}{|c|c|c|c|c|c|c|c|}
\hline Isolate & Serotype & $\begin{array}{c}\text { 3D } \\
\text { rRT-PCR }\end{array}$ & $\begin{array}{c}\text { 5'UTR } \\
\text { rRT-PCR }\end{array}$ & $\begin{array}{l}\text { Combined } \\
\text { rRT-PCR }\end{array}$ & $\begin{array}{c}\text { 3D } \\
\text { mRT-PCR }\end{array}$ & $\begin{array}{c}\text { 5'UTR } \\
\text { mRT-PCR }\end{array}$ & $\begin{array}{l}\text { Combined } \\
\text { mRT-PCR }\end{array}$ \\
\hline IRL 6/2006 & Negative & - & - & - & -- & -- & - \\
\hline Neg Bov epi & Negative & - & - & - & - & - & - \\
\hline Neg Bov epi & Negative & - & - & - & -- & -- & - \\
\hline Neg Bov epi & Negative & - & - & - & -- & -- & - \\
\hline Neg Bov epi & Negative & - & - & - & - & -- & - \\
\hline Neg Bov epi & Negative & - & - & - & +- & +- & - \\
\hline Neg Bov epi & Negative & - & - & - & + & + & + \\
\hline Neg Bov epi & Negative & - & - & - & +- & -- & + \\
\hline Neg Bov Epi 1/7/2006 & Negative & - & - & - & - & - & - \\
\hline Neg Bov Epi 1/7/2006 & Negative & - & - & - & - & - & - \\
\hline Neg Bov Epi 1/7/2006 & Negative & - & - & - & - & - & - \\
\hline Neg Bov Epi 1/7/2006 & Negative & - & - & - & - & - & - \\
\hline Neg Bov Epi 1/7/2006 & Negative & - & - & - & - & - & - \\
\hline Neg Bov Epi 1/7/2006 & Negative & - & - & - & - & - & - \\
\hline Neg Bov Epi 1/7/2006 & Negative & - & - & - & - & - & - \\
\hline Neg Bov Epi 1/7/2006 & Negative & - & - & - & - & - & - \\
\hline Neg Bov Epi 1/7/2006 & Negative & - & - & - & - & - & - \\
\hline Neg Bov Epi 1/7/2006 & Negative & - & - & - & - & - & - \\
\hline Neg Bov Epi 1/7/2006 & Negative & - & - & - & - & - & - \\
\hline Neg Bov Epi 1/7/2006 & Negative & - & - & - & - & - & - \\
\hline Neg Bov Epi 1/7/2006 & Negative & - & - & - & -- & -- & - \\
\hline Neg Bov Epi 1/7/2006 & Negative & - & - & - & -- & -- & - \\
\hline Neg Bov Epi 1/7/2006 & Negative & - & - & - & -- & -- & - \\
\hline Neg Bov Epi 1/7/2006 & Negative & - & - & - & -- & -- & - \\
\hline Neg Bov Epi 1/7/2006 & Negative & - & - & - & -- & -- & - \\
\hline Neg Bov Epi 1/7/2006 & Negative & - & - & - & - & -- & - \\
\hline Neg Bov Epi 1/7/2006 & Negative & - & - & - & -- & -- & - \\
\hline Neg Bov Epi 1/7/2006 & Negative & - & - & - & - & -- & - \\
\hline Neg Bov Epi 1/7/2006 & Negative & - & - & - & - & -- & - \\
\hline Neg Bov Epi 1/7/2006 & Negative & - & - & - & -- & -- & - \\
\hline Neg Bov Epi 1/7/2006 & Negative & - & - & - & -- & -- & - \\
\hline Neg Bov Epi 1/7/2006 & Negative & - & - & - & -- & -- & - \\
\hline Neg Bov Epi 1/7/2006 & Negative & - & - & - & -- & -- & - \\
\hline NEG BOVINE EPI & Negative & - & - & - & -- & -- & - \\
\hline NEG BOVINE EPI & Negative & - & - & - & -- & -- & - \\
\hline Negative bovine & Negative & - & - & - & -- & -- & - \\
\hline Negative bovine & Negative & - & - & - & -- & -- & - \\
\hline Negative bovine & Negative & - & - & - & -- & -- & - \\
\hline Negative porcine & Negative & - & - & - & - & +- & + \\
\hline Negative porcine & Negative & - & - & - & -- & -- & - \\
\hline BHU 1/2003 & NVD & - & - & - & -- & -- & - \\
\hline BHU 47/2002 & NVD & - & - & - & - & - & - \\
\hline BHU 5/2004 & NVD & + & - & + & -- & -- & - \\
\hline IRN 15/2005 & NVD & - & - & - & -- & -- & - \\
\hline IRN 4/2002 & NVD & - & - & - & -- & -- & - \\
\hline IRN 6/2005 & NVD & - & - & - & -- & -- & - \\
\hline IRQ 39/2002 & NVD & - & - & - & - & - & - \\
\hline IRQ 44/2002 & NVD & - & - & - & - - & - - & - \\
\hline
\end{tabular}




\begin{tabular}{cccccccc}
\hline Isolate & Serotype & $\begin{array}{c}\text { 3D } \\
\text { rRT-PCR }\end{array}$ & $\begin{array}{c}\text { 5'UTR } \\
\text { rRT-PCR }\end{array}$ & $\begin{array}{c}\text { Combined } \\
\text { rRT-PCR }\end{array}$ & $\begin{array}{c}\text { 3D } \\
\text { mRT-PCR }\end{array}$ & $\begin{array}{c}\text { 5'UTR } \\
\text { mRT-PCR }\end{array}$ & $\begin{array}{c}\text { Combined } \\
\text { mRT-PCR }\end{array}$ \\
\hline IRQ 58/2002 & NVD & - & - & - & -- & -- & - \\
LAO 16/2003 & NVD & + & + & + & ++ & ++ & + \\
SYR 6/2002 & NVD & + & + & + & ++ & -- & + \\
SYR 7/2002 & NVD & - & + & + & -- & -- & - \\
TUR 17/2002 & NVD & + & - & + & -- & -- & - \\
UKG 36/94 & NVD & - & - & - & -- & -- & - \\
UKG 37/94 & NVD & - & - & - & -- & -- & - \\
UKG 39/2002 & NVD & - & - & - & -- & -- & - \\
UKG 40/2002 & NVD & - & - & - & -- & -- & - \\
\hline
\end{tabular}

